\title{
Real Life: The Story of Stem Cells
}

\section{Bhaskar Vyas* and Rajni Vyas}

Department of Microbiology, Stem Cell Research Division, Total Potential Cells (P) Ltd.

and Samanvaya Trust, Vadodara, Gujarat, India

*Corresponding Author: Bhaskar Vyas, Department of Microbiology, Stem Cell Research Division, Total Potential Cells (P) Ltd. and Samanvaya Trust, Vadodara, Gujarat, India.
Received: September 14, 2020

Published: November 18, 2020

(C) All rights are reserved by Bhaskar Vyas and Rajni Vyas.

\section{Foreword}

Stem cell therapy has a long gestation period since the first stem cell was identified in the early twentieth century. It is almost a hundred years that the discovery process passed through different stages of identification, description of properties, isolation of stem cells, and finally the application of stem cell therapy for therapeutic purpose or regenerative medicine in the twenty-first century. One could explain this delay in terms of several factors. It is not only due to the promulgation of germ theory and antibiotic revolution that pushed the biological diseases to the background for a long period but also because of the impact of the II ${ }^{\text {nd }}$ World War and changing state and science relationship. After the demonstration of power that the detonation of nuclear weapons generated and expressed in terms of the fetishism of force that the physical sciences gained greater public visibility and consequently greater funding at the neglect of biological sciences. This was also reflected in the reward system and the discovery of every new particle was honoured with a Nobel prize in the subsequent decades even if it became a routine science. A positive outcome was that the $I^{\text {nd }} W W$ gave rise to ethical concerns for medical research and led to the establishment of the Nuremberg Code for human experimentation to combat racism or Nazi ideology. Finally, this movement evolved into the Helsinki Declaration and several revisions till 2013. However, Science got divorced from values or ethics and scientists started eschewing social responsibility for the application of science that they evolved.

It was not until the eighties that the biological sciences restored some respectability and that ushered into the biotechnology revolution. Along with this, the other technologies that emerged were information and communication technologies and nanotechnologies. These technologies co-evolved with an intertwined phenomenon of globalisation and the international environmental movement. Biotechnologies revolutionised the health sector and promised to treat several intractable diseases. At the same time, this phenomenon posed several challenges of social, economic, political, legal, and ethical nature. During this period ethics also reentered the realm of science.

Curiosity in stem cell research was further kindled with the disentanglement of properties such as self-renewal and potency. Unlike plant stem cells that could be differentiated into any cell, the animal stem cells have different potency like totipotent, pluripotent, multipotent, and that only totipotent stem cells could be differentiated into any organism. More importantly, the totipotent stem cells were found only in embryos. After 1999, scientists discovered that manipulating adult mouse tissues could produce different cell types, and later the first embryonic stem cell lines of a human cell were derived. It was the use of human embryos that mainly raised ethical concerns. The understanding of cell biology also improved that led to the reprogramming of adult stem cells into totipotent stem cells reducing the ethical burden. It is after this period that stem cell research picked up momentum and there was a proliferation of stem cell research and clinics for stem cell therapy the world over. This included not only a genuine quest for research and therapies but also the world witnessed a proliferation of rogue clinics exploiting gullible patients including donors/vendors of oocytes of from women belonging to vulnerable sections. Many of these clinics advertised and promised unproven treatment. Different countries have followed different kinds of regulatory regimes ranging from restrictive to liberal regime leaving space for many researchers or

Citation: Bhaskar Vyas and Rajni Vyas. "Real Life: The Story of Stem Cells". Acta Scientific Microbiology 3.12 (2020): 43-74. 
doctors for their overzealous pursuits. The technological spread of stem cell therapies did not remain confined to the metropolitan centres of the advanced countries but there was rapid diffusion in the developing countries including India. This was reflected in an increasing number of research publications and patenting activity. India figures as amongst the top fifteen countries as far as world publication ranking is concerned.

Given the wider socio-economic implications of these technologies, a need for socioeconomic studies became imperative as well. I also started studying this phenomenon from a science policy and innovation system perspective along with my Ph.D. students. I had also undertaken a collaborative research project with a prestigious university in the UK. It was during this time almost a decade back while I was visiting my hometown Vadodara that I came across a newspaper report about a doctor who was engaged in stem cell research and therapy. My curiosity was fueled by astonishment that doctors were dealing with an emerging area of science and technology in a relatively 'small town' called Vadodara. The upshot is that that in the globalized world the technological diffusion is rapid and the technological gap between the advanced countries and developing world was not wide in the emerging technologies. I could not resist calling him up for an appointment. This was Dr. Bhaskar Vyas, a plastic surgeon of international repute, who immediately granted me the interview, and the very next day allowed me to visit his clinic-cum-lab and discuss the implications of stem cell research. This professional association continued later with several seminars and meetings where he agreed to participate.

Recently, to my great delight, he approached me to write a foreword to his memoirs surrounding his work on stem cell research. As far as autobiographies and memoirs are concerned, it is easy to find many scientists publishing autobiographies but it is not so common to find such work authored by doctors or medical researches. Here, you have memoirs penned by him and his wife Dr. Rajniben and a short chapter contributed by their daughter from the UK. This work describes their journey through an uphill task of stem cell research and challenges that are faced by any pioneers. They have a racy style of writing that is iterative at times and jumps that make the readers think and captivate their imagination. It is about the unknown and unraveling of stem cell science. The book begins with their jousting over bureaucratic controls and overcoming the hurdles and about people who understood the value of stem cell research and extended a helping hand. The path of narra- tion meanders at times into experiences of meeting great doctors and researches or at time bursts into poetic expression and philosophical twists or into finer details of stem cell science that would interest specialists as well any common reader.

These memoirs compel readers to rethink or redefine the ethical guidelines for stem cell research aimed at balancing between the urgency of medical need and abuse of this new science and technology and commodification of human organs. The socioeconomic, ethical issues and risks are further compounded by the allied and emerging technologies such as gene editing. This technology involves greater risk while editing heritable characteristics. The complexities involved will certainly rummage the minds of inquisitive scholars. Finally, I leave the readers to ride the horses of dreams along with the authors.

Pranav N. Desai

Former Professor, Centre for Studies in Science Policy

School of Social Sciences, Jawaharlal Nehru University

New Delhi

August 8, 2020

Contents:

About this book

Genesis of the beginning

Pollution Board Clearance - Ms. Gauri

H.L. Trivedi - BAPU

National Science Congress - Prof. Balu

Indravadan Modi

Gentleman Varshnay - A Blessing from Saibaba

National Science Congress - 2006-07

Beginning with 0

Open Sesame

Frayed feathers, ruffled relationships

Turnabout and turncoat idealism

At Prime Minister's Office and thereafter

Nobody can deny an idea whose time has come: Regulations will come and go

Conference at Jawaharlal Nehru University: Collaboration with King's College, London 
Even pay to publish, since it is an addiction.

Eureka! A new drug discovery

Clear out entire forest: cut not a single tree

If wishes were horses, we surely will dream

\section{About the book}

This book is an autobiographical narration of the research activities, with penchant and passion, by two leading clinicians who turned towards stem cell research in later years of their life. The book is about facts as they happened, it also includes fiction as it should be a part of any novel and there is fantasizing as well as what one would like to be in the future. Facts, fiction and fantasy are frequently flavoured with philosophy as well. The authors axiomatically classify themselves as philosophers. Advocating that philosophy is the mother of all disciplines, they narrate how they jumped into deep waters of expensive stem cell research. The book describes how did they blunder at times and also cites the appearance of guardian angels to salvage them. Floundering from cell biology to different kinds of stem cell applications, the book describes where they have now parked at a far horizon, on the edge of new discovery of a wonderful drug. They ignite a spark of caution with restrictive regulations. The book ends with reframing the poem by Rabindranath Tagore, 'Into that heaven of regenerative medicine, my Father, let my country awake'.

\section{Chapter 1 Genesis of the beginning}

The source of inspiration: "WHO?".

This autobiography is the about work of two comrades. Comrades in arms. When we decided to be life partners, it happened at an academic conference. Yes, there would have been romance, love, family relationships, bonding and convergence of consciousness to the extent of consilience. There were discussions, debates, dialectical discursions and difference in opinions but when it came to act, there was total agreement and unity. But the most precious ingredient of this conjugal relationship is comradeship. Comradeship in action. Neither of us alone would have been able to accomplish any one of the real life stories recited herein.

It should be remembered that the autobiography is about the life and work of two persons: What is accomplished has been conceptualized mainly by me and effortless eloquent execution has been done by Rajni. One would not be complete without the other. Before narrating further, we need to make one clarification.
Autobiography by its very nature is written in a first person singular. However, there is radical departure here. This is the real life story of two persons. This has been happening all throughout our lives since we began to live together. For simplification the narration would be by me. But it implies a masterly execution by Rajni. Moreover, let us not enter into dialectical discussion as to whether happenings occur like a descent from the sky or they can be manipulated as a structure. It is certain that this story happens to be written by the application of multiple, multifaceted intelligences. A countless number of high profile scientists and several young brilliant scientists contributed to the development of the full story. The story has impacted their lives.

Stem cell research is like an ocean. Ocean has no beginning and no end. Its depth is variable. There are numerous pebbles on the seashore. This real life story concerns about our gathering a few pebbles as we walk on the beach and wet our feet with sea water.

Regardless, what Krishnamurty said about a pathless land, it is true over here also: the first step is the last step. Therefore, each chapter is readable as an independent short story and so all chapters are numbered as 1.

Before 5000 years, some 'Rishis' heard voices from the sky. Whatever may be their state of consciousness, they remembered what they heard. It was passed on verbally from generations to generations since there was no script. The first of the Vedas, 'Rig Veda' is described as "voice heard from the sky" from divine origin'Apaurusha-not authored by any human being'.

The 'Rishis' conceived that individual minds may also get interconnected. A state of high connectivity between human beings would then give rise to a cosmic web. It was conceptualized to exist universally and the mind was thought to be a receiver like radio. Therefore Rishis prayed, 'Let noble thoughts come to us from all the sides”. Significant as it is, 'Rig-Veda' does not describe any God or Goddess but what is stated is undoubtedly eternal truth. This may be so when understood in a poetic sense. Most people would like to call it instinct. This is a fundamental attribute of all human beings. When subscribed to by giant individuals like Mahatma Gandhi it may be called as a voice within. A modern age 'Rishi' may poetically illustrate it as, 'a moment reveals what heavens toiled to express for ages.' The aim of the present work is not to engage in this kind of dialectical, philosophical discussion. The work is about a simple answer that we have sought as a quest. Yet, not to find 
and yet not to yield; and search endlessly without accepting defeat. Thus it is a story about our pursuit for the answer to derive from our stumbling into the field of stem cell research.

We Indians somehow or other have this trait of sky gazing and hearing voices from "Above". This has happened to us and that is how we sat down to write this story. There were several different paradigms that could become a good love story full of romance, passion and disappointment, there were times full of adventure, fulfillment of ambitions and failures and there were times when dreams did come true or significantly crash. We have never thought any one of them to be of important to write. There is nothing to eulogize but most situations have had a human face to show. $\mathrm{Hu}-$ man faces that were full of aspirations, hopes, surety to endeavor and ability to withstand bad weather as well as gratuitous graces and munificent magnanimities that showed up spontaneously. We thought such a portrait gallery may be with indistinct faces of the authors, but full of vigor with the participants engaged. That would make a good gallery to show.

We have been believers in some kind of "divine design". When the events materialize from nowhere and catapult into a structural design, we would call them a happening. Scenic amongst my friends and readers would frown, "happenings? What divine design?".

But the aim of writing this is simply to tell a story. There is no aim to prove any scientific point of view whether the story is science or philosophy or both. As Carl Jung has written these are just happening.

Our basic training is in the discipline of science. We wondered at the physicality of matter and speculated about how the basic chemical elements got as rhythmically arranged as described by Mendeleev ${ }^{1}$. When we trained as medical students, we were amazed how a malarial parasite will find its way into red blood corpuscles, multiply and in turn can be killed by a small pill.

Study in a medical school was for us an experience like Alice had in 'Wonderland'. Every bit of knowledge that we gathered was inculcated in our minds with a sense of wonder, surprise, astonishment and awe. A transformation occurs in the consciousness with these kinds of mental vibrations.

Shri Aurobindo has beautifully described this wonderland as follows:
- In the blue of the sky, in the green of the forest, Whose is the hand that has painted the glow? When the winds were asleep in the womb of the ether, Who was it roused them and bade them to blow?

- He is lost in the heart, in the cavern of Nature, He is found in the brain where He builds up the thought: In the pattern and bloom of the flowers He is woven, In the luminous net of the stars He is caught.

Shri Aurobindo, titled the poem as 'Who.' In his poetic effulgence, he carries his search with 5 more stanzas and finds him sitting alone in the darkness thus.

- When darkness was blind and engulfed within darkness, He was seated within it immense and alone.

Yet, we derived the inspiration with further question, such as what, how, and when that man sitting in the darkness alone seems to be working all the time. This is the factual genesis of this real life story of stem cells.

We cited the poem since we found Shri Aurobindo advocating on our behalf that whether happenings happen or divine design exists or not, it can certainly be seen as a shadow in a bright moonlight.

However, philosophy is the mother of all disciplines. A myth or a fantasy may also transform into philosophy when chiseled with sharp logic. Fantasy so occurs that, at times someone may fool around most people, most of the times. Charles Darwin (18091882) travelled across the globe on the ship, 'Beagle' collecting the fossils from several islands to come out with a brilliant hypothesis'Theory of Evolution'.

At this point Vatsal stopped transcripting and looking intently at me, he asked

"So, the theory of evolution is a hoax?".

"No, there is no hoax. Evolution is a philosophical concept that has no empirical evidence".

"The fossils collected by Darwin are not evidence?".

"There is no empirical evidence that your parents were monkeys and tracing the ancestry to the limits of your family memory, there would not be any. Science today accepts evidence even for sub-atomic particles. 
To produce that kind of evidence, Charles Darwin will need to reincarnate again and again and produce a video graphic film of transition. Therefore let us not waste time in brilliant philosophical hypothecation".

Suffice it is to say that the logistic triggered a few geniuses.

With such a brilliant exposition as advanced by Charles Darwin, the intelligentsia world-over were amazed at that time. Shri Aurobindo (1872-1950) prophesized that evolution also evolves. With apology to Shri Aurobindo, it may be said that philosophers, particularly when they pronounce a prophesy need not and do not provide any empirical proofs. A literary genius, George Bernard Shaw (1856-1950), wrote a play, Pygmalion (1913) and is still being played and displayed in several languages world over. The fantasy involved transformation of a street vending flower-girl to pass on as a princess in 6 months of articulate training in speech and elegant dresses. That was of course great entertainment.

But a real life experiment, based on the fundamental conviction of theory of rebirth and reincarnation was put in practice by Anne Besant and Leadbeater. They picked up a destitute boy from a sea beach at Chennai-the then Madras. The boy is a legend today in the form of J Krishnamurthy (1895-1986). He transformed numerous lives. This transformation of J Krishnamurthy is a living proof that not only the miracles still happen but, a miracle may also be brought about!

We derive further strength to our logic by citing a few excerpts from yet another poem by Sri Aurobindo.

\section{The Dwarf Napoleon}

Behold, by Maya's fantasy of will

A violent miracle takes sudden birth,

The real grows one with the incredible.

In the control of her magician wand

The small achieves things great, the base things grand.

This puny creature would bestride the earth

Even as the immense colossus of the past.

Napoleon's mind was swift and bold and vast,

His heart was calm and stormy like the sea,
His will dynamic in its grip and clasp.

His eye could hold a world within its grasp

And see the great and small things sovereignly.

We cite excerpts from yet another poem by Shri Aurobindo where a dwarf- a small occurrence of a dwarf human being advances to gigantic dimensions.

A Dream of surreal science

A thyroid, meditating almost nude

Under the Bo-tree, saw the eternal Light

And, rising from its mighty solitude,

Spoke of the Wheel and eightfold Path all right.

The poems are cited for their inspirational qualities. If one were to think of Napoleon, one should also remember that he met his Waterloo. However, it may have happened that, "Meditator under a Bo-tree" may have guided subtly. During the period of the stem cell work, we were closely connected with the Dalai Lama. Fourfold expression of this connection in the form of Amitabh, Avlokiteshwar, Ratnasambhava and Amoghasiddhi Buddha including the feminine form Tara have been the symbols for our meditation in this journey. We trust they were really the mentors beyond all mentors to guide.

Our study of anatomy did inspire a lot of awe and respect for the design of the form. Intricate design of structures and organs within the body must have been crafted by some superhuman being. The rhythmic function of physiology so as to automatically correct any dysfunction within a specified limit would defy even cybernetic autocorrections by a supercomputer. Even when pathology professors and authors of textbooks such as William Boyd, with a great flourish of language were warning not to see any teleological design in the process of inflammation, where white blood corpuscles will migrate to the required site and would like to term the process as Chemotaxis- a process mediated only because of the shift of molecules-it was difficult for us not to ask, but who designed chemotaxis?

'Gray's Anatomy' is a work of several geniuses. The book running into over 1200 pages was required to be memorized precisely, particularly if the student was to be a surgeon. The students were provided with some grace whereby the first chapter on The Cell was omitted from study. Thus after having had a successful surgical career extending to even sculpting human body as a plastic 
surgeon, having discharged a social obligation to the society with more than what I have got from Mother India and having probed even into esoteric realms of states of consciousness, I thought my journey should end now. Fate had other designs for us.

How long would it have been incubated in the subconscious is difficult to guess. But it began in 2004, when I attended the Indian Science Congress at Gandhinagar, Gujarat.

\section{Chapter: National Science Congress - Professor Balu}

Almost all stem cell science students in their innocent naivety would have dreamt of producing a clone - a complete organism. It can be elegantly argued that if an embryonic, pluripotent stem cell can give rise to a full human form in uterus, it can certainly do so provided an environment needed for an embryo in uterus can be created in a lab. Elegance of such logic will provide the first proof that this is indeed plausible.

Such happenings would occur only when the mind is overflowing with joy. Beautiful ideas would be full at brim when they are true. Aesthetic idea, even in hard core science would eventually fructify as truth. Let us derive a further substance to the argument as evidenced from a conversation recorded with Nobel Laureate, Paul Dirac, a professor of theoretical physics.

'Questioner: Prof. Dirac, your work is on quantum mechanics and quantum electrodynamics. Does it not amount to a mere abstraction?

Dirac: No, there are mathematical proofs.

Questioner: But there is no experiment, no empirical evidence in an experimental lab. And the mathematics is only on paper. How do you verify your theory?

Dirac: Yes, my work begins with mathematical equations on paper. I only need a paper and a pencil. But, when everything flows with perfect elegance, I know that this theory is most likely to be true. Elegance, beauty, aesthetics and truth are interwoven.

With this state of mind, I started demurring about the phenomena of a single clone. The sheep 'Dolly' will live for eternity in history as the first and last clone produced out of a stem cell created from a somatic cell. Dolly was cloned by somatic cell nucleus transplantation technique. The nucleus from the ova of the donor sheep was transferred to the udder cell of the recipient sheep cell and was put in the surrogate sheep which gave rise to first sheep clone 'Dolly'. This experiment was done in Scotland in 1996.

'Dolly' suffered from joint problems all over her body. The sheep died after a short life due to lung problems, however cloning is now banned across the world. This is because in spite of being a pinnacle of scientific achievements, such research was a clear violation of time honored ethics. There was an outrage from the Church. It certainly threatened the future of humanity. Yet, every stem cell researcher will like to bask in the glory of such a creation.

Towards the end of the $20^{\text {th }}$ century, another kind of stem cell research that drew worldwide attention was for the treatment of Parkinson's disease. The most potent stem cell is embryonic stem cell. This cell has properties to regenerate into any of the organs. Embryonic cells derived from aborted fetuses were used in the research to develop a treatment from Parkinson's disease. Though it worked, it was a clear violation of ethics. The then President of USA, personally a devout catholic banned stem cell research all together. This was like throwing the baby out with the bath water.

The next president, Barack Obama was petitioned by some 34 top stem cells scientists that they will move out to Europe unless this decision was revoked. Barack Obama lifted the ban arguing thus: Science, Research and the laboratories have endless patience but a patient cannot wait. His life is threatened and his time is limited. Benefits of cutting edge science research are his prerogative to ask for and should not be denied.

India also put Stem cell research as a funding priority. And, with this kind of atmosphere an entire day was devoted at National Science Congress, 2005 at Ahmedabad, Gujarat.

We met Dr Noshir Antia at the session.(he was the first Indian to be trained in plastic surgery by A. B. Wallace at Edinburgh ; I was the last Indian to be trained by Mr. Wallace). It was a pleasure to sit next to him to listen to some "cutting edge science research" about stem cells.

I asked him; "What are you doing here?".

He said, "Learning about stem cells"

I asked, "Learning, at your age? About stem cells?".

Dr. Antia sat through the session till the lunch break!

It was inspiring to see someone of his seniority still eager and keen to learn. 
Although, overall there was a paucity of basic science research presentations, there was some compensation when Dr. Dorairajan Balasubramanian delivered his presentation on stem cells from the limbus. Limbus is a junctional area between sclera and cornea that is studded with stem cells. In normal life the limbal cells constantly keep regenerating the cornea.

At the onset, the speaker provided some humor by announcing that his name is wrongly spelled. He should be named simply "Balu". And at the end he introduced his protégé, a young ophthalmologist, Virendra Sangwan. He had salvaged many eyes by using limbal stem cells. Thus even a corneoplasty was not warranted.

I met Virendra Sangwan several times thereafter. We visited him at L.V. Prasad eye institute in Hyderabad., Professor Balu and Virendra were extremely humble and graciously gave us a tour of their stem cell lab. They further introduced us to their gentle stem cell scientist, Gita Vemuganthy.

Looking at their lab we were struck as to how simple the design of the lab was. Immediately in our mind we could see that we could reproduce a stem cell lab at Vadodara. There were no anterooms to the lab, there was no changing of the dress and a few scientists including Dr. Gita were in simple white coat aprons.

Dr. Gita introduced us to an inverted microscope. I confess that till this date we had not seen an inverted microscope!

We asked Dr. Gita, "Why do you call it inverted?".

She replied, "Because the objectives of the microscope are under the stage (unlike the normal light microscope) and light source is over the stage".

Like a school boy I asked, "But then how can object be viewed if it is under the stage".

She replied, "When you look into the eyepiece you see the object to be viewed. That is the arrangement".

And half jokingly and half serious asked, "Have you come to LVP to see some stem cells or understand how does an inverted microscope work?".

She showed us Limbal stem cells in the initial stage following harvest from the limbal region of the donor eye. She further showed us how after culture the cells come together to form a membrane akin to the cornea.
Dr. Gita told us her story of how she came to be involved in stem cell research. To begin with she was a child specialist. Then she converted herself to a pathologist. The third generation as a stem cell scientist came about due to a transformation by Prof. Balu.

On the stem cell platform she had advanced by leaps and bounds and had travelled the world. She had conducted several workshops to teach prospective scientists about limbal stem cells.

Imagine out surprise when a few years later, Gita wrote us a sad, sentimental farewell letter. She wrote that she was leaving stem cell science with a heavy heart since she had been offered deanship at a medical college. What a loss to the cause of advancing science!

A few years later we wrote to her about the possibility of researching stem cells for regenerating retina in a blind eye. Regrettably she would neither accept to be a part of the project nor could she find a way to facilitate us.

Strange are the ways that people in various situations assigning value to their work. To our esteem, Gita was on the peak sublime, so why would she have agreed to the ridiculous domain of administration? Maybe there was a clash of egos?

Let me talk about our dealings with various scientists at the National Centre for Cell Biology, Hyderabad.

Dr Balu was the head of the institute who was succeeded by Dr Lalji, both eminent biotechnologists. After retiring from the NCCB, Dr Balu became mentor at LV Prasad Eye Institue in Hyderabad. We had planned to approach Dr Lalji with a plan to see if he and Dr Balu both could work with us together on a project. We were forewarned, that if you mention Dr Balu's name, then there would be no collaboration with the NCCP.

We accepted that prejudices prevail in the scientific world. WE decided that we will try and recruit both of them to help without mentioning one to the other.

We also met a cell scientist at NCCB who was a cardiothoracic surgeon. He asked us, " Do you want to repeat the mistake that I have done?".

We understood what he meant. It was an abject admission of a mistake to change his career from clinical to laboratory research. There was no point in discussing his mistakes. We requested him to take us to the science laboratory. We understood that laboratory 
research is painstaking slow and rewards are difficult to accrue. WE also have collaborated with one further cell biologist at NCCB, Hyderabad. To start with, we will like not name him. Vatsal suddenly looked at me and stopped transcribing.

He asked, "We have been mentioning most people by name, why do we not mention him?".

I answered, "The situation changes to a different paradigm when the relationships between the subordinates and the superiors are concerned, particularly in a government job".

"What is the shift? I do not understand".

"In such a situation, organizational behaviour gets so complex that it becomes archetypal. Are you familiar with archetypal relationships in a Hindu family, such as mother-in-law and daughterin-law relationships?".

"But that was the mentality which is fast vanishing in modern society".

"Yes, it will be a good evolution for the families and the societies. Few decades ago a British historian and author Parkinson wrote Parkinson's Law. He became famous by articulately defining the relationship between a subordinate and a superior officer. Simply stated, it can be said to be an existence between a dog and a cat or between a cat and a mouse. The law states that there is a spontaneous, inbuilt jealousy between the first and the second rank in the hierarchy everywhere".

The relevance of not mentioning this brilliant cell biologist by name lies in the fact that we did not want him to suffer by inviting the ire of his superior".

On our first interaction with this cell biologist, he asked,

“Dr. Vyas, how many patients would you have benefitted so far?".

"Difficult to count. Innumerable".

"And the patients have now stopped coming to you?".

"When we decided to quit clinical practice, our hospital was overflowing".

"Have you killed any patient?".

"No. But some did die under our treatment".

"Of course that can be understood.
"But let me summarize that I have killed numerous mice and other animals. This was with the hope that my research may ultimately benefit the patients".

"What has happened as of now is that I have a prestigious position at a national institute. It has allowed me to live and nurture my family-this is the only benefit accrued to me by this position I would be happy to give you the entire protocol to use for patients who need it, say burns and such other injuries".

"That is indeed kind. But, we may not be able to afford it. What would be the approximate cost".

"You will give me happiness, a sense of satisfaction. And no money will change hands". (More details later)

He was true to his word; he collaborated to submit a project for funding under Small Business Innovation Research Initiative - SBIRI. The project was written by him. The project was titled, 'Future potential of the keratinocyte as a somatic cell translating into pluripotent stem cells'.

I decided to send him an email. Vatsal quickly shuffled several screens on the desktop, stopped transcribing and instead sent the following email to this scientist.

'Dear Dr.

Last time we communicated was when you told me about your promotion to a higher authority. You are very much in our memory for your kind courtesy during the visit to NCCB. We wrote a project together as well. Kindly do let us know how you are and what projects are you working on?

With regards,

Bhaskar and Rajni Vyas,

Stem Cell Researchers,

Vadodara.'

By written mail he wrote a reply.

'Dear Sir,

Namaskar. It's a pleasant surprise for me to have received your email. I am very blessed that you remembered me.

I retired from CCMB in April 2017 as Director Grade Scientist. I had been Research Director at Basavatarakam Cancer Hospital and

Citation: Bhaskar Vyas and Rajni Vyas. "Real Life: The Story of Stem Cells". Acta Scientific Microbiology 3.12 (2020): 43-74. 
Research Center for about 2 years.

I am now associated with a start up company (which one of my students started) and involved in producing therapeutic proteins for cancer therapy.

Hope you and all the members in your family are doing well

Best personal regards

Sridhar.

He further wrote: "Basically we are now developing technology to produce immunotherapy drug Pembrolizumab. We have got a world bank-DBT Grant to do this. As per the projections, we need to keep clone ready for clinical trials by next year. Hopefully we will succeed with blessings from You all.

Secondly, it's a basic and routine protocol that measures cancer cell viability after treatment with any drug. That's the start point".

Thus reconciled that Dr Sridhar Rao was no more in a subordinate position, we felt comfortable to mention him by his name.

Let me continue the story of our first encounter with him. The cell biologist, Dr. Sridhar Rao Kunchala, explained the elementary difference between a cell and a stem cell. His institution was working on the functions and properties of a cell. His work was focused on cells from the surface of the skin(keratinocytes) of humans and animals. He was working on this cell so as to be able to prepare human skin-like substitute that could be used for treating major skin defects.

My eyes blinked: Eureka!

This was one of my earlier dreams when I had thought of treating my burns patients with cultured keratinocytes. But he explained that this cannot be taken to clinical use because he has not been able to find a substitute for the deeper layer of the skindermis. Without this support, the keratinocytes would not survive.

He had spent more than 20 years of his life to develop one cell line. We wondered which way would this dedicated scientist be inferior to Yamanaka who had recently developed a pluripotent stem cell from a skin fibroblast. We understood the answer in our mind. The Indian scientist had the same genius as the Nobel Prize winning Japanese. The difference was not in the seed but in the soil.
We wrote our first project for funding from Government of India in collaboration with Dr. Sridhar Rao. We thought that together we should be able to produce a substitute for human skin. This was to contain a base similar to dermis. Unfortunately, the project was not funded, however it opened a window to approach Professor Padmanabhan that we will narrate in the next chapter.

It is not uncommon for scientist of high eminence to harbor jealousy against colleagues. Vatsal interrupted and said, "But Indian ethos has been different since time immemorial.

Let us study together

Let us eat together, enjoy together

Let us engage in adventure together

So that together we shall excel".

"Yes, this was fundamental to a lifestyle in the times when Krishna and Sudama studied together. It is probable that centuries of alien rule has corrupted this noble idea".

We happened to discuss this incidence with our friends, colleagues and, even the Dalai Lama. In His inimitable style he said, India is our guru. A 'chela' that I am, I should not find fault with the guru. When further prodded about the Buddhist culture in Japan and the present Indian Hindu ethos, He said imposition of any culture over other is not good. That is the reason why Tibet does not want to be under Chinese domain.

When further questioned, the Dalai Lama expounded thus: Today, most Japanese are practicing Buddhists. They live by the Buddhist precepts and practice them in real life. Compassion and kindness are basic to Buddhism. Thus, conflicts are avoided and may be resolved as well. Avoidance of conflict, even in the mind, saves mental energy. The surplus energy finds its outlet by enhancing creativity.

He was on his favorite theme, Buddhist tantra. When we continued asking for further elucidation, he initiated us to the formal learning of Guhya Samaj Tantra. That was indeed a byproduct of our search for stem cell research. Further discussion is unwarranted here since it will be a distraction from the main story. The dialogue with the Dalai Lama is still in progress encompassing different dimensions that do not include stem cells.

We are now knitting the story once again back to Dr. Balu and stem cells.

Citation: Bhaskar Vyas and Rajni Vyas. "Real Life: The Story of Stem Cells". Acta Scientific Microbiology 3.12 (2020): 43-74. 
The academic gain from the session at The Indian national congress of Science in Gandhinagar was to make the acquaintance with Prof. Balu and Virendra Sangwan. We mused the obituary of A. B Wallace with Dr. Antia and were about to part when an announcement came. Cadilla pharmaceutical was sponsoring a workshop with two Korean scientists later that evening. Everyone was invited. I darted off and was the first one to register.

I had few other instances when I met Professor Balu. We had no knowledge about the guidelines for stem cell research. Gujarat State Biotechnology Mission, (GSBTM) invited all stem cell researchers and scientist from Gujarat to discuss the scenario and academics regarding stem cells. Professor Balu was in Chair. He made an oblique remark without mentioning Dr. H.L. Trivedi. He said, "I am told that there are some fly by night scientist in Gujarat etc." I protested that there are no fly by night scientists -they have done a yeomen's service to humanity. But worst was still to come when a scientist sitting next to me was asked to describe what he is working on. Dr. Himanshu Patel started describing how he has produced myocardial cells from stem cells and help treat 78 cardiac patient in cardiac failure. He had barely finished when Professor Balu flared up. "So here is fly by night stem cell scientist". He lambasted Dr. Himanshu and proceeded to tearhim to pieces I had to intervene.

I said 'Dr. Balu, if a scientist has helped 78 cardiac patients with a fastidious process like culturing myocardial cells, and published his work; kindly tell us what is so fly by night about this?'

I had forgotten that I was speaking to one of the highest authorities in India in the scientific field. Probably this might have been for the first time that Prof. Balu would have been accosted thus by a novice. Everyone was stunned. After some silence Dr. Balu said yes there may not be anything wrong. But the regulations have not been followed.

Thereafter we had made a permanent friend with Dr. Himanshu Patel. However, Prof. Balu was correct; not on scientific grounds but on legal terms. A detailed discussion is warranted on the subject that had profound implications on our work and our future, we shalltalk about it later. A few times after this incidence when our paths crossed with Dr Balu on scientific terms, we greeted him with high regards. He has made immense contributions by becoming a mentor to LV Prasad eye institute including sourcing a even a confocal microscope for the institute. He has cordially reciprocated my greeting by an informal, 'Hi Bhaskar!'
We have decided to focus on what is good and turn a blind eye to what is sordid. Regulations are needed for all kinds of activities and a good government with good governance without any corruption is the primary need to regulate. WE reiterate and dare to say that stem cell therapy is futuristic. Even when a single spinal cord injury or amyotropic lateral sclerosis of spinal cord patient benefited so as to live a productive life with stem cell therapy, further advancement of research is warranted. Alas! The regulations in India are drafted - crafted with a copy and paste of 'advanced nations,' primarily FDA, USA. National newspapers including The Hindu gave front page coverage that a stem cell researcher - medical doctor may be punished with a revocation of his medical license and imprisonment of up to 2 years if they did not adhere to the rules laid down by the government of India! Even Virendra Sangwan, a profulgent pioneer of limbal stem cell research, a protégé of Prof. Balu that received the Rashtrapati Award for best young scientist of the year, was forced to admit that he had not conducted any clinical trials. It seems history repeats itself-under the threat of execution by the Church, even Galileo even had to admit that the earth was flat!

The current corona virus pandemic has forced a radical rethink in how news drugs and vaccines are brought into clinical use. $\mathrm{Nu}$ merous drug trials have been fast tracked the world over and the race to produce a new vaccine is promised to bring it to the front line within months rather than years.

\section{Gentleman Vishnu Varshney - A Blessing from Saibaba}

We have lived the prime time of our life in a close fisted pseudo-socialist economy in India. Following liberation and globalization, we learnt new terminologies such as angel investors, venture capital funding, etc. We doubted the existence of such entities. My daughter Nirupa, (A MBA in finance and a doctorate in the share market) verified that, not only are they operative in Gujarat and India, but they succeed as well.

Hence we decided to approach Gujarat Venture Finance Limited at Ahmadabad.

Within a few days, I received a phone call. The caller said, "Dr. Vyas, I am the official in-charge of finances at GVFL. I would like to speak regarding your proposal. Would you kindly keep our talk anonymous?". With a pleasant surprise, I said, "Yes, of course. Please speak".

"I am aware about the potential benefits of stem cell therapy. My new born baby boy had a birth defect. He is alive and progressing 
following stem cell therapy. I have spoken to Mr. Varshney about this. So he is suitably inclined to fund you venture. He is likely to call for a presentation soon".

"That is splendid, we will meet you then".

"I have moved for a better position elsewhere and I am being relieved today. Best of luck to your efforts".

So here was a guardian angel, materializing from nowhere! I said to myself, "If a guardian angel has spoken, surely there will be angel investors as well!!”

I had to move fast, I realized. I wrote down the cheque towards payment of the plot for Biotech Park, Savli and started making a presentation together with Rajni and other members of my team. We have presented academic research at the conferences pertaining to our medical subjects. This was an entirely different challenge.

This was however our first ever presentation on stem cells. More over we had prepared highly optimistic visions of what would happen in 2010, 2020 etc. for smaller informal presentations on stem cells We had absolutely no idea about how to present to potential investors whose primary aim was to generate a profit from this proposal. We were invited to present to Mr. Varshney at Ahmadabad. The first projected slide read as thus: 'Survival of the fittest'.

Survival of the fittest or the adaptable to accommodate, to adjust, to fit, to accept - concession or yielding.

Survival strategy - in response to physiological or pathological demands. Adapt - to conform to changes in environment internal and external.

To accommodate, to adjust, to fit, to accept - concession or yielding.

Most cells have the inherent plasticity.

Vishnu Varshney stopped us right away; he said "Please be specific. We do not like to have multiple colors and disjointed statements. Tell us about what you wish to do with your products".

We skipped several slides and projected the next one.
Drug Discovery -'There are many reasons to be interested in stem cells, one of the most prominent being their use in finding better drugs to treat human diseases. This presentation focuses on how this may be implemented. Recent advances in the production of reprogrammed adult cells and their regulated differentiation to disease-relevant cells are the products, and diseases that have been modeled using these methods are discussed'.

Varshney nodded, "This is a little better. Move forward".

Avoiding the academic distinctions between the varieties of stem cells, we focused on the limbal stem cells from the junction of sclera and cornea to benefit patients with corneal defects, how the stem cells will be converted into myocardial cells that can benefit a patient with heart failure and how a stem cell transforms into a nerve cell which can benefit a neurological patient.

Varshney asked, "Do you mean that such a cell can help a brain stroke patient?".

"Yes, there is enormous literature support. But in India so far there are no clinical trials".

"And what about spinal cord injuries?".

"Korean scientists have demonstrated the beneficial results of stem cell transplantation in patients with spinal cord injuries".

"What would you say about a baby born with meningocele?".

I paused and wondered, did the baby mentioned by the finance manager on the phone have such a defect?

"There are several grades to this condition. And we do not know the status of stem cell with them".

We presented the project cost estimate at Rs. $10 \mathrm{Cr}$.

When we concluded our presentations, Vishnu Varshney began his comments: Your project is well articulated academic study but it is highly ambitious.

We will advise you to restrict your research to a single product that can be taken to commercialization as soon as possible. It may take about 3 years and your projection to yield profit in a year or so is ill-founded. 
I could not hide my disappointment. I did not utter a word but gave up a deep sigh. Varshney saw my body language and said: "GVFL not only funds a start-up, we shall become your stakeholders and will provide a mentorship too in the domains that you will need for sure, such as marketing, business promotion and future expansion". You have hurried up to acquire a large area of land at Biotech Park that is not necessary for a start-up but we will take this on our books. I thought what is the next missile that he is going to aim to me? Fortunately it came as a bulldozer creating a pavement erasing an obstacle. "Your project estimate is $10 \mathrm{Cr}$. That also is not needed for a start-up. GVFL does not have much money. Your total funding requirement is $10 \mathrm{Cr}$. out of which GVFL will like to fund you with $2 \mathrm{Cr}$ !”

I could not believe my ears!! I got up and extended my hand with a few steps forward towards Vishnu Varshney and said "Bhagwaan Vishnu, you are our truly incarnate Bhagwaan. Thank you, thank you very much!"

He dismissed his team and asked our assistants also to leave. Thereafter he switched over to an informal friendly mode. In a relaxed easy-chair, he almost rumbled in a monologue as how he learnt about the concept of a venture fund in USA. How he was the first one in India to bring the concept to Gujarat. With what difficulties he could barely pursue the existing profit making business houses to participate in raising equity so that GVFL can be incorporated. His estimate was that if 3 out of 10 funded start-up companies would succeed, that would be enough for GVFL to keep afloat. 7 out of 10 funded companies by GVFL are profit making. He also gifted us a few books written by him regarding venture funding. At this time, one of our team members entered and reminded that we had to catch a train from Vadodara to go to Bombay that evening.

But Bhagwaan Vishnu laid down a totally unexpected condition. He said, "I am a firm believer that the entire cosmos is governed by divine forces. I further believe that Satya Saibaba of Shirdi, though not in physical form now, is still functioning as an arbitrator so that the divine grace accrues only for the benefit of large masses of people. His benevolence so ordains that the Divine Grace descends only in the right direction. It can never do any harm".

"Yes Mr. Varshney, we are firm believers in your philosophy. We had a pilgrimage along with our daughters to the shrine at Shirdi".

"Oh, and what did Sai tell you? To go to Vishnu Varshney?".
"We spent one night at the shrine, we hoped that the fabled Saibaba does give Darshan in the early morning in the courtyard of the temple. We got up at 3:30 A.M and in the courtyard, we saw numerous other people, aspiring with the same motivation. We waited till dawn, the crowd started dispersing. We also made our way to a tea stall with a thought that Sai may have found more worthy people than us to bless. Or he may have thought that we may also be satisfied that he has already blessed us. Though our selfish wish to see an evidence, may be rather obscure in the form of an apparition of Sai Baba moving around blessing the devotees".

"Saibaba did not speak to us, but maybe he prodded in our unconscious domain to approach you and GVFL".

"Okay then, I have put up a small shrine of Saibaba in the extreme western end of the hall, go and ask for his blessing. I repeat this has to be done if you wish that you will benefit with your association with GVFL".

Hurriedly we rushed to the small, elegantly decorated shrine, pledged our obeisance and left GVFL and Ahmadabad driving at a crazy speed of $100 \mathrm{Km} / \mathrm{h}$. With or without our knowledge, maybe Saibaba protected us on the highway and we made it to the train with seconds to spare.

My mind was neither on the highway nor with the dangers of the speed. I was absorbed about how the blessings from Saibaba will descend and, with an axiomatic query that "Is Saibaba god? And if so, where does God exist, etc".

Apparitions have been a subject of our wonder and disbelief, but given to argue on both sides and having read the stories narrated by Dilip Kumar Roy such as his works as 'amongst the great' and 'miracles still happen', we keep on searching and have not given up. In the course, we came across a spiritual person at Theosophical Society, Chennai. We narrate the story that he told in $1^{\text {st }}$ person narrative. He asked:

"Do you believe in God?".

"I do and I do not, it depends upon circumstances".

"I was a confirmed atheist to myself and to the rest of the world and I confirmed that God, you do not exist, so I don't believe in you".

"I was standing on a high cliff of Alps Mountains and my foot slipped. I happened to fall. At that time I shouted, “ God, I do believe 
in you now, I cry for help and please help!" at that time my hands came to clutch upon a root jutting out of a cliff and I stopped falling.

I continued to shout, "God even when I told you that I now believe in you and asked for help. But you do not exist, so how would you have helped me? I let go the root that my hands were holding. Continued to fall when I heard God shouting back to me, "My dear devotee, the root that you were holding was my hand!" The rest of the story is for all of us to believe or not believe but surely to have a good laugh.

How is a belief generates the physiological changes in a human being is articulately worked out by Bruce Lipton in his treatise on Biology of Belief. But we have probed deeper into about how the domain of a human brain connects to the universe. Intense meditative thought is the creative power of thought. How the creative power of thought cannot be explained even with the equation propounded by Einstein; e= $\mathrm{MC}^{2}$ is well known. But it may take a long time to exactly decipher the mechanism of transfer of creative power of thought to formative facilitation into material realization of visualization. We believe that visualization should be practiced again and again to generate and strengthen formative facilitation. This is how creative power happens.

Idea is the first reality. Atom bombs that exploded at Hiroshima and Nagasaki are empirical evidences on a massive scale. This real life story of stem cell is also a miniscule of empirical evidence of this fact.

At this juncture of transcription, Vatsal invoked Epicurus. And Epicurus started speaking thus:

"Is God willing to prevent evil, but not able? Then he is not omnipotent.

Is he able, but not willing? Then he is not malevolent.

Is he both able and willing? Then whence cometh evil?

Is he neither able nor willing? Then why call him God?".

At this instant Nietzsche shouted: "Yes there is no need. God is dead". Thus spoke Zarathustra repeatedly in four volumes. However Einstein resurrected God a few decades later with a public dialogue with Neil Bohr proclaiming.

Einstein: Quantum theory is probabilistic. I cannot believe that God is playing dice with the universe.
Neil Bohr: Einstein, leave the God to do his work. As physicists, let us carry on with our work founded on sound mathematical equations.

Here Stephen Hawkins interjected; I can prove that there is a divine design utilizing Newtonian physics only: On the contrary with elegant equations I can also prove that probabilities do exist and the outcome is determined simply by a chance observation.

This multiple dialogue can go on probably till eternity and still the choice will have to be individually since there will be no conclusion. But this will stray us away from our limited agenda of Saibaba's blessings vis a vis funding by GVFL.

Vishnu Varshney kept his word. A few days later, he visited our premises with a professor of pharmacology, Dr Harish Padh, a biotechnologist working as Director of B. V. Patel Pharmaceutical Education and Research Development Centre. Varshney introduced Prof. Padh and said he would assess our research capabilities for further innovations.

When I summarized my published papers, more than 30, pertaining to surgical procedures and my innovative surgical practices, Prof. Padh simply nodded his head. Obviously he was not interested. But when Rajni talked about her publications, his face lit up when she talked about her concept of psychodynamics of unexplained reproductive failure. Her paper had used a modified Huener's test which was published as Vyas' modification. Psychotherapeutic treatment to combat the immunosuppression at the cervix had succeeded in helping couples with unexplained infertility to have children. He asked for the hard copies and immediately reverted back with many thanks and congratulations.

Before leaving our premises to see the allotted plot at Biotech Park, Savli, Varshney approached Rajni and said, "I am impressed. GVFL is interested. I do not lie, I will give you money and I am an honest man. There is no phoney business with Varshney. He talked about two of his proposals; one which he had turned down and another which he had invested in. A lady from Vadodara came with a good proposal but when she talked about the processing cost, etc. I shelved her proposal. I was an investor in another company based in Vadodara for a few years. After successful commercial transition to make pure water with reverse osmosis process, I left the company.

We will move forward soon, let the Grace of Saibaba prevail". 
We went into proactive prospective projections as to how to deploy Rs. 2 Cr. We commissioned an architect to design a laboratory at Biotech Park. We made a list of equipment to be purchased. We listed the alternatives for transport from Vadodara to Biotech Park. Such activities continued for some time when we received a short, terse note from Vishnu Varshney around the time of Janmashtami (Shri Krishna's birthday), thus: GVFL regrets that we will not be able to fund your company. The reasons are as follows:

- We do not like that you have professorial advisors from the University.

- The investment in land will be a top-heavy, unnecessary investment.

- There is a railway crossing that involves delays at the junction with the road. There is too much time wasted.

Firstly, we did not understand that this is a turnabout and a closure. Then agitation and resentment began to mount. This time along with Nirupa, I went to GVFL and absolutely un-business like asked Varshney, "We have seen a gentlemanly Vishnu Varshney, Vishnu the protector deity of the universe. But now probably there would be a thousand names to Bhagwaan Vishnu. How have you come about to the point that you now have become a Ranchchoddeserting us?".

Varshney kept his cool. He would have been justified to ask us to quit. There was no commitment to explain. But in his suave protective ways, he said, "Dr. Vyas, you are a surgeon. I understand that you will not have really known how business gets conducted. Your daughter will understand me for sure, that GVFL is a limited company. There is a board that finally decides the matter. They have to assess the profitability and repayment feasibility". He spent a few minutes talking directly to Nirupa about what transpired at the Board meeting. What were the real objections, etc.

Turning at last to me, he said: "You have a qualified talented daughter. Induct her into the company". I was still indignant. Bordering almost to stupidity, obstinately I retorted, "I do not believe in nepotism!"

"No Dr. Vyas, this is being unfair to you own family. But it is your choice".

We drove back to Vadodara, this time leisurely musing to ourselves as to why Saibaba's grace did not descend. Or, was he really unbenevolent executioner of the divine plan so as to dissuade us from an honourous task. Surely the debt has to be paid back, business executed with generation of profits. This had to be done when we were in our 70s. We may have been truly blessed by Saibaba when our selfish projections of ill understood self interest may not have been granted.

This acceptance of the denial may also be attributed to a neurotic defence. However, we have come to understand that we have learnt to act with courage and conviction and not reflect on the outcome. This has certainly given us stable and lasting friendships whenever we interacted with new people. This is evident by a recently protracted negotiation for a collaboration with a confirmed devotee of Saibaba again, that also crashed. He expressed a sense of guilt for what happened. We wrote back, "We conclude, with profound faith in our scriptures that everything that happens, happens only as an expression of Divine Will; nothing will ever happen without the Grace from the Divine-Daivam. Let the Grace of Saibaba prevail".

\section{National Science Congress -2006-07}

The Hyderabad Conference in 2006 was held with primary focus on agriculture. Our search for advancement in stem cell science was futile. Even looking for novel ideas in scientific fields, we came across only one presentation that we remember today. It was about an innovative modality to assess sexual stimulation in a male frog by counting the number of times the frog will assume a particular position! A significant gain in the knowledge pool was to make friendship at the first meet with Dr. K Sridhar Rao. We have discussed the collaboration with Dr Rao in an earlier chapter.

The next Indian Science Congress was scheduled to be held at Amity University. I attended this conference alone as Rajni was unable to accompany me. When I started the process of booking my ticket, I came to know that there was a change in venue. It was to be held now at Chidambaram, a small town in South India. Where was this township named Chidambaram? And how would the change have happened? I took some time to decipher that such a change can only be manoeuvred with all powerful financial arms of the Government of India! The estimated budget for Indian Science Congress that year was $\sim 75$ crores INR that was to be funded by the Government. The road to the hitherto unknown town Chidambaram passed via Pondicherry.

Once again science of stem cell was hardly existent at this Congress as well. But I stumbled upon one more collaborator that was interested in stem cell research. It so happened that I put my hand, 
rather condescendingly on the shoulder of, who I thought to be a young man who was rushing past and said,

'Young man, take care, you could have fallen.'

He replied, "I am Prof. Gopal Kundu. Because of my short stature, I am frequently misunderstood as a post-graduate."

"My apologies, Professor. Where are you working?"

"My lab is at NCCS, Pune. I have half a dozen PhD students working in my lab".

"Oh, I have visited NCCS last year. I met the director to ask facilitation for our stem cell research. Don't you think he's rather conservative?" Little did I realize that this was a wrong question to an immediate subordinate to the director. When I had met the Director G. C Gupta, he was generous with hospitality but would not even open the conversation about facilitating stem cell research. I had wanted to discuss chondrogenic translation- (stem cell that got converted into a cartilage producing cell with calcification) from stem cells that were produced by Prof. Vani at NCCS. Even on further nudging, Director Gupta had not obliged. Of course, he had guided me to Prof. Ramesh Bhonde".

Therefore the expected answer from Dr. Gopal Kundu was, "I invite you to my lab. At that time we will see what is possible".

"When can I come to visit?".

"I am co-sponsoring an international conference at Lonavala, on translational research. Register and come over. I shall be glad to see you there".

This meeting graduated to writing our first funded project for DBT (Dept of Biotechnology, India).

However there was a different dimension that was delivered to us whilst we were at the congress.

One evening, I decided to drive down to the famous Natraja Temple in Chidambaram. The shrine was so vast that it would have taken me more than a week to study various sculptures and their associated history. What a wonderful panorama it was! I wondered why his temple was not included in one of the most splendorous heritage of mankind! After sitting in awe for a short time when I decided to leave, the chauffeur asked me, "Would you not want to visit Patanjali Cave?" I had not heard of this before and requested him to take me there.

Entering the cave without doors was like the first step of Alice in Wonderland. The cave was like a long, long corridor. On each side of it were rows of lighted oil lamps. I could not venture to go beyond a few steps. And as I sat down, a subtle calmness descended upon me. It was mesmerizing to visualize that in this very cave, Maharshi Patanjali had taught 3000 disciples more than 2 millennia ago! And I started hearing the voice of Maharshi expounding what would he have meant with a short, terse, Sutra: Ritumbara Pragnya. With profulgent enlightenment of my own intuitive insight, I realized how a spontaneous generation of Ashta-Mahasiddhi would accrue to a meditator! In this moment of timeless experience, I merged with That Alone that Is.

I do not know how long I sat in this experience. A gentle tap on my shoulder brought me back to reality. "It is already getting late and we should reach the venue till the dinner will be served". I acquiesced to his request although I was still basking in the spray of noble thoughts that came cascading like a huge waterfall. That was to provide a genesis of yet another book, 'Space, Time and Consciousness: Rationale of the Paranormal' which is not in its $2^{\text {nd }}$ edition.

I abandoned the morning session the next day that was entirely devoted to discuss Leishmaniasis. This parasitic disease occurs in India, only in the southern region and is unknown to Gujarat and further north. I decide to pay a courtesy call to a professor of anatomy Ramaswamy, who was in his late 70s. Rather than being a courtesy call, it transferred itself into high academics. The professor would have guessed that the aspiring stem cell scientist would not have known some of the marvels that Nature provides in designing the human body. When he asked me at last, "What is the nerve supply of cornea?".

“Ophthalmic nerve?”.

"No".

“Optic Nerve?”.

"Optic nerve, second cranial nerve terminates inthe retina. The nerve supply to the cornea is by the ophthalmic branch of $5^{\text {th }}$ cranial nerve. Name the $5^{\text {th }}$ cranial nerve".

“Trigeminal nerve". 
"Yes. And is it a myelinated nerve?". (Nerve supplying the sensations to the body structures are provided with a sheath. The sheath is made with a protein structure called myelin.)

"Yes".

"Why do the nerve fibres supplying the cornea not provide opacity to the cornea? I would rather answer than tax you further. Just as the fibres of this branch of myelinated nerves enter transparent structure of cornea, they lose their sheath! What makes the fibres lose myelin? That is the wonder of the Nature. If you believe in God, (which Prof. Ramaswamy and I firmly do), it is God who wants every human being to have a transparent cornea and yet have the sensations as well".

From profound depths of anatomy, he transgressed to his pilgrimage to Amarnath. He then took out a gong from his drawer of his table. He tapped it with a wooden stick. And Aha! There came a long reverberating sound of A...u...m... As a parting gift he gave the gong and the stick to me! That still rings and reverberates as a spiritual memory of the professor.

I left Chidambaram treasuring this precious and priceless experiences deep down in my unconscious mind. Only to remind once in a while that promises are given and they will be fulfilled. I spent a day at the Aurobindo Ashram before reaching Chennai Airport. Although the brief had been to understand stem cell research in Chidambaram, I cam away with divines experiences that have nourished us both since that time.

The best beginning is with zero: Jump into turbulent waters

There is a word in Hindi and other Indian languages- Swabhaav. I find it difficult to translate the word in English. Deeper probing into semantics of this word may take it to a state whereby the genes responsible for property particular characteristic cannot be deleted. It is an ingrained lifestyle. Swabhaav may be decided by culture, family environment, multi-lateral influences in upbringing and the impact of powerful personalities and for the scientific minded, it by differential gene expression. This is also the subject of current debate-Nature v/s Nurture. What was my Swabhaav that I jumped into the Ganges at Haridwar in an attempt to swim(much to the consternation of onlookers and causing sheer panic for Rajni and our daughters)? On a much more noble intent what would have inspired us to delve deeper into studying the science of stem cell is an enigma and may require in depth psychoanalysis. And it may still be futile. It is suffice to say that when we decided to do research in stem cell science, our knowledge was at the level 0.

We have referred to Gray's anatomy earlier. The book is a masterpiece that merits to be preserved as a cultural heritage of mankind. And only in 2015, $41^{\text {st }}$ edition of the book has a chapter on stem cells and regenerative medicine, which we continue to read even today! This emphasizes that in learning, repetition and revision are warranted and beginning at 0 will not amount to once again starting at the beginning.

We shut down our g multi-specialty hospital that had occupancy of about $120 \%$. Family and friends politely tried to dissuade and some others said at best "utter stupidity!"

We were polite to decline but defiant not to give up. Our motto was derived from Jean Christophe, a hero in Romain Rolland's novel, 'To strive, to struggle; not to find and yet not to yield.' We said, "I gave up my specialty with a new birth in this life as simply as an inquirer. Associations and specialization are the organs of protection of interests by the concerned groups. Though I would like to remain an evergreen student, if you were to read the names of Nobel Laureates, they have transgressed the narrow confines of their specialization. Stem cells have been studied for more than 100 years and yet there is not a single textbook on the subject".

Study of the chapter on cell biology in Gray's Anatomy yielded two collateral benefits; the most wonder of all wondrous discoveries could be said to be the use of Carbon Dioxide in cell culture. Who would not think that it is truly wondrous to know that stem cells need to be cultured in an atmosphere of 5\% Carbon Dioxide only!

Discovery of a free radical, Nitric Oxide (NO), sounded almost like 'Eureka!' to us. And the revelation of two other molecules produced with variance in the valency was also a novel discovery to us. We had known Nitrous Oxide as a short term anaesthetic gas. We had known of an accidental death due to mistaken over-usage of this gas instead of oxygen. This had happened during our student days and thereafter, the cylinders of Nitrous Oxide have been differently coloured than Oxygen. However, Nitrogen gas, that constitutes about $80 \%$ in ordinary air changes its properties radically in human body, when there is a change in its valency.

Valency is the combining power of an element so that in combination with a negatively charged element it constitutes a molecule. Anaesthetic gas is $\mathrm{N}_{2} \mathrm{O}$. When Nitrogen changes its valency from 4 
to 2 it combines with a single Oxygen atom to produce a different kind of gas with amazing properties. This free radical has been playing key roles in transferring information in almost all the cells of the body! This is one of the ways as to how cells talk to each other. It is a signalling molecule involved in many physiological and pathological processes. It can exist in the bloodstream for only a few seconds. Even then, in a short period of time it can produce a cascade of signals.

A similar story, that of the Carbon molecule also produces an Aha! experience but in a reverse direction. It is commonplace to understand that carbon dioxide $\left(\mathrm{CO}_{2}\right)$ is deleterious and body throws it out with every expiration. Is it not an amazing phenomenon that the best cell culture (multiplication of cells) is obtained using $5 \% \mathrm{CO}_{2}$ ?

If Carbon was to imitate nitric oxide (NO), carbon monoxide (CO) should also have some similar functions, but we all know that it is more poisonous that carbon dioxide $\left(\mathrm{CO}_{2}\right)$. Every inhalation of cigarette smoke does involve a small, miniscule inhalation of carbon monoxide (CO). Injurious effects of smoking are largely attributed to nicotine, but there can be no doubt that a small quantity of $\mathrm{CO}$ also contributes to smoking's adverse effects.

Yet another discovery was the fact that feminine sex, ordinarily known as the second sex is biologically untrue. Mitochondria are the powerhouse of the cell. The energy mechanisms are dependant on the functions of the mitochondria. Instead the mitochondria in the cells of females are more powerful! We wondered: did the worshippers of Devi Durga see the dance of female mitochondria!

My Swabhaav has generally tended to find the shortest route. I have considered that the shortest distance between two points is a straight line. But a person in search of shortest route can end up cutting corners.

This can lead to accidents. I was soon to realize that learning stem cell science through textbooks will also involve similar hazards.

The time honoured route to becoming a surgeon is to undergo residency training for at least 4 years. My university in Gujarat permitted an alternate route of 5 years that can be pursued after having taught as a tutor in anatomy for 1 year. Utterly naive, in the very first year of my exposure to clinical medicine as an intern, I wondered how nice it would be to derive some income as a tutor in anatomy and still be a surgeon albeit only a little later. At that time, I was working with a missionary surgeon at Limbdavalu (I.P. Mission) Hospital, Anand. Dr. Rutherford was the chief without the usual demeanour of surgeons of that time. He would invite interns to his residence, feed us and play harmonium after dinner. So I ventured to ask him about the alternate route.

His reply was, "If you want to learn swimming, you have to jump in the water. Without dirtying your hands, what kind of surgeon would you make?".

I understood, and walked along the well-charted path to be a surgeon.

For the emerging science of stem cell, where are the institutions, the guides and the mentors in India?

We had registered as delegates when we came to know that Indian Science Congress is holding its annual conference at Ahmadabad, Gujarat in 2005. We had great expectations. National conferences dedicated to our disciplines have always discussed recent advances. Indian National Science Congress was indeed a jamboree of science, that the scientists should be celebrating the national and international achievements of the last year. Since independence, the inauguration of the conference was done by the Prime Minister of India. This time one of India's greatest scientist, President APJ Abdul Kalam was also to be there. Some Nobel laureates were also invited.

Glancing through the pages of brochures, I realized that most of the presentations could have been a doctorate thesis. There were no Nobel laureates. Disappointed, I called home to tell Rajni not to take the trouble, since there does not seem to be anything about stem cells. So I went alone trying to keep an open mind. A notable feature of the Science Congress was the inclusion of every subject that had even the slightest pretence to be science. I attended a few presentations in home science section. It was good to know that we should use all types of cooking oils in a cyclical fashion. Similarly it was essential to have different types of pulses in the diet to ensure that all 13 essential amino acids were included in the diet. Omega-3, an essential fatty acid, was a new discovery for me. Yet, I had not seen anything about stem cells. I was happy to be proven wrong as seen by narrated happening in an earlier chapter. I was thinking of leaving without attending the last half-day of the conference. 
But another happening was yet to happen. I saw Dr. Naushir Antia walking towards me. He asked me,

"Bhaskar, what are you doing here?".

"Sir, the father of modern Indian plastic surgery, what are you doing here?".

"I am presenting a paper!". he said.

This was not listed in the brochure! I sat down for the concluding session as a courtesy to a senior pioneering colleague. Little did I know that it was to pay rich dividends. There were two presentations; one was about the stem cells from limbal region of the eye by Prof. Balu followed by practical applications of cultured limbal stem cells for damaged cornea by Virendra Sangawan, an ophthalmic surgeon. They invited us to LV Prasad Eye Institute and later, facilitated a scientist to learn culture expansion of limbal stem cells.

We followed up our quest by attending two more Indian National Science Congresses at Hyderabad and at Chidambaram as narrated earlier.

We wrote a collaborative project with Dr. Shridhar Rao, which was aimed at providing a skin substitute. Burn injuries are widespread in India. As a plastic surgeon, I had looked forward to create such a substitute for a long, long time. Shinya Yamanaka won a Nobel Prize for a research based on a somatic skin cell that can be translated to a pluripotent cell in 2012. We ventured to mention this in our project as afuturistic possibility! The project did not succeed. A scientist from GoI (Government of India), Shashikumar who was working for SBIRI called up one evening. He said, "The project was brilliantly written. But GoI is interested in finding and funding such projects that will benefit at a large scale the common masses. Your business plan and marketing strategy are really poor".

Shashikumar was a thorough gentleman, he did not expect and I repeat, he did not expect any kickbacks.

Subsequently, when I was next in New Delhi, I met Shashikumar at his residence and learnt from him how to write budgets, marketing strategies and business plans!

After our first successful funding we paid a courtesy call to Shashikumar. This time, on a Sunday morning, he met us on the grounds of a huge school campus. He happened to be the executive trustee of the foundation. He was very happy for us but politely declined to accept a small donation to the school trust. He gracefully accepted a small toy for his recently born son.

Shashikumar had explained his Swabhaav thus; we are a generation born after Independence. We have understood the merit for an upright self respecting personality. We have also understood the need for an outreach beyond bureaucracy. You may call this a personal virtuous trait; we would like it simply to be a further extension of performing our duties.

We would have wished that this personal perception of the duties of a government servant would be widespread. But we understand that generalizations could be erroneous. Shashikumar was bound to rise in hierarchy and may have even retired by now. Suffice it to say that he was truly a good Samaritan.

Shashikumar's suggestion that we pay a courtesy call to Prof. Padmanabhan (he was the chair of the interviewing committee for the projects) proved invaluable.

I had asked:

"Are you sure? No, no. This would amount to approaching the examiner before the exam".

"The times have changed. And, so have the personalities. Even New Delhi is not the same as it was a decade ago. Be sure that Dr. Padmanabhan is astute enough to weed out the chaff from the wheat".

I wrote out a short request with the subject 'Guidance for unsuccessful project'. Prof. Padmanabhan promptly granted an appointment to meet on $26^{\text {th }}$ January!

A post graduate student ushered me into the office of Prof. Padmanabhan. Yes, there was no mistake. It was $26^{\text {th }}$ January, a national holiday and the professor had already performed the duty to salute the national flag!

He was kind to the extent, a first formal meeting would permit. There was no hectoring nor condescending. Most of the discussion, lasting for about an hour, was about how to write the project. Only assertion that the learned professor made was not to show off what and how much one knows. He explicitly said that mentioning the translation of a somatic cell to pluripotent stem cell by Shinya 
Yamanaka was not warranted. He concluded by saying that we should write a fresh proposal so that the expert committee would get a just estimation of the scientific merit as well as how the money spent by Government of India would ultimately percolate to a larger benefit of large masses.

The meeting fructified. We were granted two projects in next two years. The first project enabled us to provide scientific proof that mesenchymal stem cells in our lab have the potential to translate into the three primary germ layers (ectoderm, that gives rise to neural tissue and skin, mesoderm that gives rise muscles, bones, connective tissue, and endoderm that gives rise to glandular tissue). We selected diabetes as an application instead of an adjuvant to cancer therapy as we felt that this was best suited for the brief of 'affordable product for a large population on a long term duration.

Subsequently, ewe were awarded another project with a bigger amount Our aim was to make a product that would atleast delay if not eliminate the need for joint replacement in osteoarthritis of the knee. It was a herculean task that tested our capabilities to the hilt especially as we had to finish the project in a specified time and money. We will deal with it in a later chapter. It will be appropriate to discuss some scientific aspects concerning stem cells.

\section{Open sesame!}

Having begun from zero, we barely began to understand the difference between cell and stem cell. We began by reading the first chapter in Gray's Anatomy. Gray's Anatomy is an epitome of what the scientific genius of human endeavor can achieve. The book was to be read and learnt in the first year of medical studies. Our curriculum found it unnecessary to study the first chapter that began with the study of a cell. But now reading this chapter was a delightful discovery.

We both were anatomists first and surgeons second. This was a prerequisite to being a good surgeon. We had no knowledge of cell structure and function and hence began a pleasant pursuit.

We refresh that human life begins with a single cell. When an ovum gets fertilized with a spermatozoa - (there are millions of sperms in a single ejaculate of semen and only one is needed to fertilize an ovum) - two of them merge to produce a single cell. This is embryonic pluripotent cell.

Fusion of ovum and spermatozoa occurs within Fallopian tube. A single cellular 'human being to be' continues to float in the Fal- lopian tube while it continues to subdivide. This further divides and sub-divides without further differentiation into a mass of cells (embryonic stem cells).

The mass would be the size of a very small strawberry, at this point Rajni interrupted:

"A very small strawberry will also be too large. The mass consisting of 8/16/32 or so cells will be a miniscule mass".

"Yes, true. But the image seen by us in the textbook of these few cells reminds me of the image of a strawberry". This mass of cells gets implanted into the inner lining of the uterus-endometrium how will it stick to the endometrium? Then one of the cells 'decides' to chart out a distinct individualistic course for itself. This is how it will form a distinctly different human being. The result of two of the cells deciding to do this would lead to identical twins. Such siblings are two different human beings with the same genetic structure. If more than one sperm were to fertilize more than one ovum, there can be still twins, triplets and rarely more but they do not have an identical genetic structure. Each of these cells are pluripotent stem cells meaning they are able to grow (i.e. differentiate) into all derivatives that constitute a human body.. How the pluripotent stem cells go on to form different organs is explained with a highly philosophical term - morphogenetic fields.

Morphogenetic fields as a concept was a new revelation to us. We had thought that it was a philosophical preset. We had heard about it from Rohit Mehta. Once when he stayed with us after returning from England, we saw that he was fascinated with the term. Every now and then he will quote, Rupert Sheldrake and talk about 'his theory' of morphogenetic fields. Rupert Sheldrake is a theosophist. And Rohit Mehta had interacted with him in Theosophical Society, London. Only when we started talking to the scientists in the fields of zoology, did we realize that the concept is scientifically well articulated. Rupert Sheldrake is a hardcore scientist, yet he had speculated about a concept that he called as 'morphic resonance'. We better restrict our discussion only to morphogenetic fields and leave the subject of 'morphic resonance' to the parapsychologists. How morphogenetic fields operate is poorly understood.

We have understood that the universe is governed by 4 fundamental laws of physics. They could also govern a physical organism. Although it is difficult to fathom how they would affect the spatial and temporal side. A morphogenetic field is generated by a group 
of cells or a single stem cell. Cells are able to respond to discrete, localized biochemical signals leading to the development of specific organs. The spatial and temporal extents of the physical forces are not well understood but beyond simple biochemistry and for sure will be dictated by such physical realities.

We speculated about what is the nature of a morphogenetic field. Surely it cannot be a fundamental weak or strong nuclear force and it cannot be a gravitational force as well. Each and every living system generates an electro-magnetic field. We therefore believe that morphogenetic field would be a specific kind of electro-magnetic force that gives special properties to a stem cell. Such an explanation would certainly leave God aside. Let the forces of Nature prevail. The cell biologists are content to accept the belief that there is a morphogenetic field. It guides a group of cells to a distinctly defined spatial location as a cell 'destined' to become part of the liver will go the space where the liver is to be located and formed and so on. Once a stem cell translates to a definitely defined organ, it loses its 'stem-ness'. Therefore, a liver cell may subdivide but it can only regenerate liver. A skin cell may divide, but it can only regenerate skin. Nature has so designed that a pluripotent stem cell must give up its pluripotency once it reaches its destination. But, the regeneration faculty is to be preserved. This is evident in the Mesenchymal stem cell.

Mesenchymal stem cells are present at various locations in the body in different quantities. They are most abundant in fatty tissue under the skin. Another location for their large population is in the bone marrow. It is postulated that this kind of cell responds to the call of Nature whenever there is a need for regeneration. In such a situation they will mobilize themselves to hone to the site of need. We believe that this will not be on a count of any teleologic(designed by God)- principle but would be most likely because of morphogenetic fields so generated in case of need.

With this understanding, we decided to focus our research onto the study and application of Mesenchymal stem cells. Incidentally it so happened that this was a permissible area of research. Subsequently there was abundance of researchers all over the planet focusing their attention on this particular stem cell. If there was a question about the existence of a phenomena termed as consilence, here was a proof that it existed.

We spent a modest amount of money from our pension fund to upgrade our rudimentary stem cell lab to a GMP Class-5 lab. GMP means Good Manufacturing Practice and cells processed with a view to administer them to human beings should at least have a GMP Class - 5 facility. WE never believed in setting modest goals and this time was no exception. We decided that we will focus on trying to translate mesenchymal stem cells into all three germinal layers. Prof. Ramesh Bhonde (Professor of Zoology, NCCS Pune) facilitated with a change in direction. He advised us to focus on adipose derived mesenchymal stem cells instead of bone marrow. That was easy and simple. Our plastic surgeon colleagues in Vadodara were generous to supply lipoaspirates that they were throwing away following cosmetic surgery. We searched for standard protocols for trigeminal translation. In contrast to the practice in medical profession, where we pride in sharing our knowledge and innovations, we have realized that hardcore scientists hold their research protocol close to their chests. If and when they share, they expect a financial return. Prof. Bhonde bucked the tide and was generous enough to give us the protocols available at his lab without any expectation of financial gain. This empowered us and in collaboration with Prof. Gopal Kundu we submitted our project to SBIRI. We were successful and the work to cultivate insulin secreting cells for ADMSC started. More on this project later. Subsequently we came across a fantastic book written by Dr. S. Janarthanan and Dr S Vincent. They have published almost all the protocols that a scientist may need for conducting research in biotechnology. Hence we could translate mesenchymal stem cells from adipose tissue into a nerve cell and a chondrocyte with only a small financial outlay.

We happened to discuss the matter with our erstwhile colleague, Dr. B. S. Anantram. Dr. Anantram, after qualifying as one of India's foremost plastic surgeon, had demurred whether to relinquish his professional career to serve a larger cause i.e. management of the charitable institutions and hospitals financed by Hegde Trust. He continued to serve mankind by treating patients at ANNASAWMY MUDALIAR GENERAL HOSPITAL. Anantram was fascinated by the research and urged us to publish our researcher as Indian Innovations. Little did we realize that when we said, yes, it would entail a fine chiselling of each and every word before publication in the Indian Journal of Plastic Surgery.

Mesenchymal stem cells obtained from bone marrow and adipose tissue are similar in their properties. Both of them have potential to be taken from bench to bedside, a cell such as cardiomyocyte (heart cell that can be seen to pulsate in a petri dish!), obtained by a process in the lab will retain only the properties of a heart cell 
and will lose the property of being a stem cell. A stem cell can be transformed-academically spoken as 'can be translated', into an insulin producing cell. These cells will have similar properties to the insulin producing cells from pancreas. They will respond to glucose stimulation by releasing insulin. They would have lost their stem-ness.

Let us see what constitutes 'stem-ness'. The properties of stem cells will differ depending upon the kind of stem cell. A single embryonic stem cell, produced by the union of a sperm and an ovum (discussion about twins is not relevant here) has the potential to bring about a new human being, with differentiation into specific organs. The embryonic cell will also lose its property with further differentiation into three specific germinal layers. This we have seen before.

Cells that give rise to various components of blood are hematopoietic stem cells. They are present all throughout life in bone marrow. This is widely researched and, is used therapeutically in over 150 conditions.

Pluripotent stem cells are those that have the capacity to generate any of the cell types in the human body. How do the cells forming different organs find their location to form an organ, say liver or heart or kidney, is highly mystical? It is postulated that a particular cell type will have a specific kind of, 'field' so that it finds its way to the specific location. This field, called morphogenetic field, is yet to be completely understood since several different disciplines will have to focus together.

In the search for the ultimate, a complete organism, named sheep 'Dolly' was produced by transforming a somatic cell to induced pluripotent stem cell. Such a search at times translates into intense quest and frenzy. To be the first one to come out with an invention has produced some weird situations.

Soon after Shinya Yamanaka was awarded a Nobel Prize, Nature published a breakthrough. The article cited research that the authors had been successful in producing a pluripotent stem cell simply by exposing them to a very low $\mathrm{pH}$. Scientists from Japan published the research in 2014 and it initially took the scientific world by a storm. What a quantum jump for regenerative medicine! Scepticism of the research quickly rose and as soon as the next issue, in an editorial, Nature apologized for printing the research. Subsequently the research was retracted!! This was only in the second time in its history that Nature had to apologise for its content.. In 1988, it had published research that water retains memory of substances previously dissolved in it. This had practitioners of homeopathy awash with delight. As the results could not be replicated, Nature had to retract the publication.

A philosopher of research in science, Thomas Kuhn, has concluded that science progresses with falsification of earlier 'established' theories. So shall we keep on making blunders so that scientific research may have a quantum jump?

Our introduction to induced pluripotent stem cells came with a handshake with C. M. Habibullah at a symposium on stem cell research in 2010, New Delhi. I participated in the symposium with several volleys and cascades of questions that extended to even genomics. C.M. Habibullah who was chairing the session came across at the conclusion of the session:

"I would like to make a clone of you!"

"Sir, do not, please do not punish with another existence!"

"No, this is a reward for your scientific spirit".

"If that is indeed so, please oblige me with standard operating procedure as to how you obtain induced pluripotent stem cell (iPSC)".

"Do come over to Hyderabad and ask for whatever you want".

Unfortunately, Dr. Habibullah passed away the next month. His son who inherited his research which regenerates liver cells in patients with cirrhosis using stem cells. This novel approach has attracted patients from all over the blood. Dr Habibullah (Jr) To reiterate his father's invitation. If there was indeed a possibility to propagate human existence as a clone, we would have certainly gone to Hyderabad.

I decided to jettison attending national science conferences thereafter. We had found plenty to learn, but not even elementary stem cell research.

Having already accepted Dr. Kundu's invitation to the International conference at Lonavala, we did attend We understood what translational research exactly meant. So far it had sounded as a high literary metaphor. What the high priests of science were endeavouring was to derive a meaningful, clinical application of their basic research. I also learnt that discovery of a new drug at that 
time would cost approximately $\$ 120$ million and journey from bench to bedside application was likely to take about 10-12 years. No wonder none of the high Pundits had accomplished this.

Most delegates were from USA with the team leader as Bharat Aggarawal (the now disgraced biochemist from the M D Anderson institute, Texas! A few presentations on turmeric were presented with clinical evidence. Most of the work was focused on molecular biology. Not a single one on stem cells!

On the positive side, there was the opportunity to develop the scientific relation with Gopal Kundu.

"I am happy that you came. Now you can ask for whatever you want from my laboratory. I expect that my research will progress soon to monkeys!".

"We would like to characterize stem cells from our laboratory with CD markers".

"We will do that. A scientist, Pompom".

"Why do you call her pompous?".

"No, she is not pompous, her name is Pompom. She will do CD markers for you and train a scientist from your lab with the technique".

Most of the scientists left the conference by lunch time. Looking at the beautiful landscape of mountain and hills, with a few fluffy white clouds floating beneath the hills, I found it difficult to move away. Bharat Aggarawal finished some paperwork and when he looked around, we were the only two left in the venue. He asked: "Oh, you are here! What are you doing?".

"I am musing on the mystical presence. And I am singing a poem in my mind. Listen to what.

I recited a few lines from the sonnet. It is so pertinent and appropriate to reproduce the poem here:

"What is this life if, full of care, We have no time to stand and stare.

No time to stand beneath the boughs And stare as long as sheep or cows.

No time to see, when woods we pass, Where squirrels hide their nuts in grass.
No time to see, in broad daylight, Streams full of stars like skies at night.

No time to turn at Beauty's glance, And watch her feet, how they can dance.

No time to wait till her mouth can Enrich that smile her eyes began.

A poor life this if, full of care, We have no time to stand and stare".

Bharat Aggarawal wondered and asked, "What is the relevance here?".

"I think the villagers roundabout are happier than most of us. They have all the time to bask in the glory of Mother Nature. I feel, our relentless pursuit of science is also a different kind of greed. By the way, pl tell me what you consider as your best research?".

"Alpha TNF".

I was amazed!

"You discovered Alpha Tumour Necrosis Factor? And you did not submit this towards a Nobel Prize?".

"I did not care".

In the ambience of high intellectualities, I was in a state of innocent naivety. Alpha Tumour Necrosis Factor is a molecule secreted by large cells in blood and similarly in tissues at the time of injury. The discovery has contributed significantly to understanding the process of inflammation. This was a huge step towards understanding the process of inflammation. I was in a state of awe and wondered as to why had this great scientist not been awarded his due? It turns out that he was stating the truth but not the whole truth! We met Prof Mande the newly appointed director of NCCB. He was meant to be more open minded in sharing research and less conservative in his approach. Two surprises awaited when Gopal Kundu conducted me to him. Kundu introduced me as Prof. Vyas, researcher at MS University. And Director Mande was even more affable and amicable than what I had heard. He had only one question:

"Why does he not conduct the research at MS University?".

"Prof. Bharat Chattoo is doing genomics. They have no facility for marker studies". 
I believe Mande was a worshipper of Saraswati. Approached differently with a recommendation from Prime Minister's Office, he had to correspond for about 3 weeks. Thereafter his office quoted an exorbitant quote to train a scientist from our lab for 5 days. The figure was just short of 7 digits! Earlier, Lalita Limaye had sat with me for half a day to familiarize me with her lab and the work on hematopoietic stem cells!!

Soon after, Pompom facilitated a scientist from our lab to conduct CD 44 marker study. The result of this study was indicative that the spindle shaped cell cultured in our lab was indeed a Mesenchymal stem cell.

We wrote a collaborative project with Gopal Kundu. It was awarded a research grant from Dept. Of Biotechnology, Government of India.

I was with Anant Marathe, team member at TPC at the time. We were ushered in for the presentation. Prof. Padmanabhan welcomed us loudly:

"Here are the researchers from Vadodara. They are being mentored by Prof. Chattoo".

Instinctively we guessed, we seemed to have already won. There were only few questions from experts.

"What is the source of your technology?".

"Technology for isolation of MSC is available as open-access".

"What is your innovation?".

"Translation of MSCs to insulin secreting cells".

"Why do you prefer to investigate Mesenchymal Stem Cells?".

"This cell line is likely to help diabetic and cancer patients".

"What is your preferred choice?".

"Diabetes"

"Why do you prefer this modality?".

"Diabetes is recognized as a national priority".

“Do you have the protocol?".

"Yes, here is a hard copy".

In a short time, we were informed that we had been successful in our application and steps were outlined as to how the funds were to be utilised and what processes were to be followed. There was a reminder that as collaborator, Gopal Kundu should make himself available when a team for due diligence would be deputed from DBT to Vadodara. As it happened, Gopal Kundu could not be available on the specified date. Prof. Sheshagiri, the chief of the three member team said, "Never mind, are you prepared to go ahead alone?". There was no alternative but to say yes.

Turnabout and turncoat idealism

Ramesh Bhonde advised a change of direction after we have studied the bone marrow derived mesenchymal stem cells for a few years. Bone marrow should be replaced by adipose tissue. We preferred this option as well. (I have performed plenty of lipo suction procedures as a plastic surgeon). Adipose tissue is easier to obtain and abundant in quantity. Bone marrow would yield about $10 \%$ MSCs; while lipoaspirate will yield 30-40\%. Dr. Anant Marathe had joined us. When we submitted the research project to DBT, Prof. Bhonde readily offered to be a mentor.

Prof. Bharat Chattoo was so far advising us about genomics. We could not afford to conduct micro array assays in human genomics as it was prohibitively expensive. We found an article Nature that could potentially provide a short cut and reduce the costs. We set up a meeting with Prof. Chattoo.

However, the professor curtailed the meeting. "Yes, it is feasible. There is yet another short cut available. You can study a limited number of genes that modulate consciousness. Thereafter whatever proteins that such genes encompass, either by their expression or suppression can be further studied in a dry lab. This is a new tool; bioinformatics".

We have discussed this with Ernest Rossi. Rossi had an elegant logistic hypothesis. He had postulated that a hypnosis therapy session conducted in the altered state of consciousness, with certain manipulations in syntax will change the semantics. This message will pass on to the genes (!) From immediate early onset certain genes will be expresses or indeed maybe suppressed. We had published a paper related to this in a Americal Journal of Clinical Hypnosis. We thought Prof. Chattoo would like to discuss this further.

When i tried to elaborate Prof. Chatto cut me short. He asked, "I understand you have applied for a DBT grant".

"Yes, but it is about stem cell research".

"Do you know that I am a member of the expert committee?"

"Yes, but we thought to discuss it would be imprudent". 
He rang up a mobile number. He asked, "When are you likely to schedule the visit by the experts to TPC, Vadodara?"

Thus we came to know that we seemed to have succeeded. Secondly we understood that Prof. Bharat Chattoo was in a commanding situation.

Soon, we received a communication from Small Business Innovation Research Initiative - SBIRI. A team of 3 members were to visit us for due diligence. We were surprised to note that we are not required to arrange for their reception at the airport. Transport was being organised by their department. We were not required to provide lunch either. Only a cup of tea and biscuits were permitted!

We were pleasantly surprised to see this new face of India that we had envisaged in our dreams. It truly reflected the personality of the head of the visiting team.

Prof. Sheshagiri was in a strict vigilance mode. One by one he verified that we had the equipment that we had shown in the documents to be in our possession. He saw mesenchymal stem cells in our lab. He verified that CD 44 marker studies were conducted at NCCS, Pune. At this point he double checked, is it sure that Prof. Gopal Kundu cannot make it to Baroda today, and moved on quickly to review few proof of concept studies that we had conducted. When he was busy reading our publications, the other two experts were more than satisfied. Without realizing that I was standing at a hearing distance, they spoke to each other, "Some researchers have taken more than $1 \mathrm{cr}$. And have not done even half of what these people have already done". At this stage we disclosed to the non scientific, financial expert that we have changed the name of the company from Total Potential Cell Pvt. Ltd. to Total Potential Cells Pvt. Ltd. We tried to explain that this was necessary because we had to withdraw from the Biotech Park, Savli. After 3 years of waiting, there was no development of the incubator that had been promised by Gujarat State Biotechnology Mission- GSBT. The incubator space was well cordoned off and yet, in spite of any building with sophisticated equipment, one can see only donkeys grazing around there.

He was not interested. He said, "All the same, TPC remains TPC. Correct?". We replied, "Yes. Same promoters. Same researchers and same team. Only a new name".
The execution and successful completion of the project happened to be a hefty challenge. Procuring 20 samples of lipoaspirates was easy. Our practicing plastic surgery friends were generous to supply large quantities of lipoaspirates. The rest of the process was an arduous task. We had to decide whether to do enzymatic digestion with trypsin or a chemical processing with a toxic substance, Fecol. We had to wait to make sure that we obtained pure mesenchymal stem cells. We managed to procure MSCs with more than $90 \%$ purity after passaging twice!

The study of cell markers on mesenchymal stem cells is an expensive task. Even the supplier of the cell markers, needed to be carefully assessed about their capabilities. Regardless, the cell markers are expensive. We wasted an entire batch of positive and negative cell markers. No refunds!. We found a guardian angel, Dr. Ansarullah who happened to be on sabbatical leave in Vadodara at this time. He selected a second supplier and there was success in store. Dr. Ansarullah, a gentle, self effacing professorial person had spent a few years in United States in Stanford University. His post doctoral research was also on the same topic: Translation of mesenchymal stem cells to produce insulin cell aggregates.

Dr. Ansarullah who preferred to be called as Ansar Aman (Aman translates from Urdu to English as peace) gave a lot of peace. He not only found the right supplier for the dye studies, helped in the characterization with four positive stem cell markers but also helped in establishing a protocol for translation of mesenchymal stem cells to insulin producing cells. He took the ICAs from our lab to conduct confocal microscope studies at Prof. Chattoo's lab. When we reviewed the confocal microscope pictures, we saw the peak of Mt. Everest right before our eyes!

Dr. Ansar stayed at Vadodara for about a year. He wanted to stay in India if a suitable research facility and salary that he well deserved- 6 lacs per annum- were to be available. Mother India could not nurture this worthy erudite professor. He is now working in Germany so that the entire planet may benefit. His stay in Vadodara was instrumental to our success.

In addition Dr. Ansar mentored Jaymesh Thadani, our senior most scientist. Together they perfected the protocols for isolation, culture and expansion of mesenchymal stem cells to islet aggregates. They also produced $\sim 500$ islet cell like aggregates that secreted insulin. They conducted the tests to prove ICAs did secrete 
insulin in the lab. That paved the way for implantation of ICAs in the liver in 6 patients with diabetes.

The year pleasantly went by in the pursuit of what was thought to be an impossible task. The task was achieved through the efforts and ingeniousness of several members of the team.

We presented the research at the annual function of BIRAC 2015, with Rajni as the presenter. We won the best research award for 2015. Even then we hardly realized that we have established a significant milestone for finding a resolution to several problems faced by patients with diabetes.

Prof. Bharat Chattoo was even more pleased than us. He egged us on to think about yet another research application. Dept. of Biotechnology had formulated a Business Ignition Grant- BIG. BIG aimed at funding such research proposals that can be taken up for a lasting business adventure. We were advised to continue with further application in the diabetic domain. Wisdom would lie in repeating what we have already done before. But that would not be suitable to our psychological profile. We decided to apply for a grant to see if we could achieve mesenchymal cell translation to chondrocytes. We discovered that such translation studies were successful in animals. But there was no studies to show if this had been achieved in humans.

Dr. Anant Marathe and I presented before the expert committee. The committee burst out into laughter when I replied to the last question that, "Several studies in different animal species have been conducted. That includes bovine, porcine, equine, etc. Only elephantine and human species are yet to be studied!"

We understood that we have been successful in being awarded the grant.

It required a lot of effort and a few visits to BIRAC that the previously funded TPC and the current TPC under consideration for funding for a new project are the same people. There is no camouflage; no subterfuge but only a force of circumstance that the incubator at Biotech Park, Savli did not materialize. Finally when BIRAC was convinced that the same researchers, same promoters are using the funding, that they released the funds after much delay.

We had 6 months to organize the team. We had to find a suitable multi-specialty hospital with more than 80 beds. We had to acquire the added equipment before the start of the project, take ethics committee and stem cell research committee approvals, and so on.
We advertised the commencement of the project in local newspapers. One hundred and thirty eight patients turned up as volunteers! Dr. Pradeep Mehta and Dr. Umang Gandhi had a difficult time in choosing the participants.

There was an opinion that we select only those with Grade 2 osteoarthritis of the knee. That would have given a surely successful result. But that would have diminished the merit of the study. In the end we decided to include in the study those patients, who had both the knees affected with osteoarthritis. We also decided to include Grade 3 and 4 stage of osteoarthritis. The patients with injuries to the cartilages within the knee as well as the ligaments were also included.

We enlarged the number of the knees studied to 50 by including both the knees in 25 patients. All the patients reported satisfactory progress, subjectively and with objective parameters of clinical assessment. We had expected that a new cartilage formation will be evident at the end of one year. There was a disappointment looming large in our minds. None of the MRI studies showed a shadow of a new cartilage formation. Have we failed? Have we failed? Have we failed?

Hope lied in the fact that except one patient, all the others were satisfied and happy. Their pain had gone. Their mobility had increased and other clinical parameters of assessment also showed improvement. With extensive literature search we understood that the type of the regenerated cartilage would be embryonic like cartilage. Moreover it will be very thin. This will be unlikely to show even with MRI. We presented the results to BIRAC. They were satisfied. When presented at Indian Association of Rheumatologists and Orthopaedic Surgeons conference, the project was awarded Gold medal for the best research.

We were a bit surprised when 2 electronic media, published from Chicago, approached us for a briefing! We had been accustomed to the times when news took a long time to travel through word of mouth. S Ramesh of India Post interviewed on Skype. Laxmanrao of Chicago Tribune came personally to Vadodara. Tamanna(a periodical) gave coverage twice. Following week, Anant Marathe phoned and we could see that he was bursting with joy. One of his friends had called up from USA and asked, "Anant, we knew that you were carved out to be a big sportsman. But never did we know that you are to make that giant size of a researcher as to climb to Chicago as well!" 
Regional Gujarati newspapers and national newspapers including Times of India publicized our research. Some researchers, while on their vacation travels to India, came to visit us. They were surprised to have a look at our modest lab. They did not doubt the veracity, but advised us to have more sophistication with a view to sell the research.

We started to get a trickle of small number of patients from USA and UK. Apart from monetary help to sustain our research, it provided a big ego booster.

Cerebral Palsy is a disorder that affects newborn and young infants. We have understood that the primary cause of this disorder is insufficient oxygenation to the brain. It was surmised that treatment with mesenchymal stem cells, while the brain is developing, may be beneficial to the children.

A young lady of 30 years, diagnosed with cerebral palsy since many years approached us with her parents. We were persuaded to treat her regardless that the outcome may not be of much avail. This young lady improved so very much that she travelled all across Gujarat, to persuade patients with cerebral palsy to come forward for treatment. Little did she understand that her treatment could be carried out because of their explicit understanding and expressed request. It would require a large scale clinical trial before it could be offered as a treatment on a large scale. When we were flooded with the requests from expectant parents, we decided to conduct a proof of the concept study with 10 patients. Doctor Prof. Usha Modi has been a long time friend. She was a puritan Gandhian: Professionally as well as personally. We had long discussions with her over a few sessions to assure her that there is a possibility that success, even in a limited degree would mean improving the quality of life of these children for the rest of their lives. She was aware of studies from national and international institutes that results were not favourable. She reluctantly agreed to participate on the explicit understanding that the Helsinki protocol will be followed in word and spirit.

We treated 10 patients. 6 out of them improved with the parameters of the milestones that were defined by Prof. Modi. Most remarkable improvement that is sustained today after almost 8 years is of a young girl. She was blind and had to be cared in a cradle till she was 12 years old. She required to be sedated during the transport from Ahmadabad to Vadodara. She was transported in a trunk of the van. Within a year of treatment, she was on her feet. She started going to a blind school and is now undergoing vocational training as a blind person. We hoped to improve her further with some restoration of sight. Her father who had suffered terribly whilst caring for her (he had lost his job as his caring duties took priority) however refused consent for any further treatment. He wanted to rest on her limited gains.

Thus we were riding high. We prepared a project for stage 1 clinical trial and submitted to Dept. of Science this time. There were many collaterals including the assessment of cognitive and other functions by child psychologists from Dept. of Home Science at the University. Over a period of 3 years, the project was estimated to cost Rs. $1 \mathrm{cr}$

Along with Rajni, Dr. Anant Marathe, this time Nirupa also went as a presenter. The expert panel consisted of only 3 members. To our pleasant surprise, we found Prof. Ganguly as chairman. In his inimitable style, Dr. Ganguly straightaway focused on Nirupa, "We have heard your mother speak before. We have thought about collaboration with her. I know the academics. I believe that this trial will cost much more than the stipulated budget. Tell me, how are you going to finance the deficit?".

"We will bear the burden as needed". said Nirupa.

"So do you expect your parents to leave you with some debt? I would not like that".

"My expertise is as a finance manager. I will find the money".

"But debts have to be paid. I don't like it". After a pause, Prof. Ganguly said, "Your proposal is rejected. Apply again when you have found some more money. Hopefully that time there will be some other person as chairman".

Rajni interjected at this point, "Yes sir. Everything else may have changed then. There will be one constant factor that Prof. Ganguly will be the chairman!" Everybody burst into laughter including the other 2 experts who were in a silent mode all the time. Although we left laughing, but our enthusiasm to present projects was fast fading.

At this juncture, a lot of advice and some pressure to sell our research started coming. BIRAC, Biotechnology Consortium of India Ltd. (BCIL), C-CAMP advised to hold our hand by mentoring. Research recognition by DSIR was due for renewal. They also asked: 
"You have been granted customs exemptions for importing your equipment, you would have derived benefit and the government would have lost some revenue. How much is the amount?".

"We have not availed of this benefit at all".

"Even then it is expected that the country should benefit with your research. Your work has been sponsored with public money".

Multinationals from Japan and other countries are buying biotech research from India because valuations appear to be cheap by their standards, etc.

So after much persuasion, at the third time, we applied for a Launching Entrepreneurial Affordable Products (LEAP) Project funding. This involved only bare academic details, the emphasis was how the proposal would be attractive to a promising entrepreneur to invest in the equity of a start-up company.

From being academics to now becoming vendors of our research, we were helped by Deepak Raja and Sandeep David. Firstly, we were made to apply for a patent. This was contrary to our ideology. We thought. C.N. Rao produced $400+$ products and is still researching for more and did not seek a patent for a single product. We were made to realize that this route was for fierce idealists of the last century who were on a full time salary at a grandiose institution. The idealism may be termed as fantastic idealism since such a fantasy can accrue only a fortunate few. Their entire research funding would have been at public expense. A small entrepreneur with an expensive hobby of biotechnology research will have to generate his own additional resources, even if some public funding was to be available.

We had known that a stem cell is a biological product, a gift of nature. It cannot be patented as per the law. When we began research, we had taken this fact in our stride. We had thought we do not want to go patenting. Let Mother India benefit. We may be called turncoat idealists instead now. We must agree that there is nothing absolute about our idealism. When survival is at stake, even God will forgive us, may even exhort us to be a turncoat. This reminds us of a brilliant lawyer, who had to execute a turnabout; still in service of his client.

The story goes that a lawyer with brilliant eloquence vehemently argued and was about to conclude when his assistant pulled his jacket and passed a short note. "Sir, you have argued in favor of our opponent". Taking a short pause, the lawyer became a turncoat. He continued, "What I said before would be what my learned opponent would say. Now I will quash each argument piece by piece and turn them to figments".

Now we take the solace, if we were to find a buyer for our research, maybe from abroad, Mother India and people at large globally will benefit. Patents have been applied and are in process. We wrote this on the day when India was celebrating Shankaracharya Jayanti (28 $8^{\text {th }}$ April). Now Shankara's philosophy is the ultimate as considered by his followers. The axiomatic truth propounded by Shankaracharya provides the generic ground of a yardstick to measure the veracity of Truth. They are as follows:

- prajñānam brahma - "Prajñāna is Brahman", or "Brahman is Prajñāna"

- $\quad$ ayam ātmā brahma - "This Self (Atman) is Brahman"

- tat tvam asi - "Thou art that"

- aham brahmāsmi - "I am Brahman", or "I am Divine"

All philosophy generated from above into different fields of discipline is relative to not only at the time and at the place but also on who is doing it, why is he doing it, how is he done and with what motivation.

We have defended our actions enough. Call it a survival strategy or term it as turncoat idealism; what matters at the bottom line is survival.

\section{At Prime Minister's Office and thereafter}

\section{Project SVISCRTH}

In 2014, there was a change of government at New Delhi. Jawaharlal Nehru, as the first Prime Minister of India, had the vision to advance India scientifically to modernity. Subsequent prime ministers had provided token support by inaugurating the National Science Congress year after year. Mr. Narendra Modi sprang a surprise for scientists in India when he decided on his first foreign tour to visit Japan. And at Japan, he visited the laboratory of Prof. Shinya Yamanaka! He saw stem cells of different categories under the microscope. At the conclusion of the Japan visit, he signed a collaboration to advance stem cell research in India.

We knew about Mr. Narendra Modi's fascination for biotechnology and stem cells. We were aware that he had allocated Rs. 60 
crores to set up a stem cell facility at Surat, Gujarat. It will be a sad story to dwell upon as to what happened to the proposed and already initiated facility after Mr. Narendra Modi left Gujarat. But we were encouraged by the Japan visit and wrote to him a congratulatory response. The letter apprised him that some of the cells that he saw at Japan were also the topic of research at our modest lab. We also mentioned that we had signed MoU with the Government of Gujarat that envisaged setting up a stem cell research lab, in addition to facilitation to advance holistic health under the title Swami Vivekananda Institute of Stem Cell Research and Therapy and Holistic Health.

We had a prompt response from the PMO. The dialogue between two secretaries and us went on to 3 meetings and correspondence for several weeks. We would like all the government officials to be role models emulating these gentlemen. They were discrete, polite, highly sensible, and probing with well directing direction. Such a description may as well be liked by most; but we sense that these high profile officials would not like to be mentioned with their proper names. Therefore we simply mention the first one whom we met as Mr. S.

Mr. S asked for a project report that they intended to be sent to ICMR for evaluation.

We shared the letter with Prof. Chattoo and other friends. Bharat Chattoo shared a few stories similar to the situation. When Mr. Narendra Modi was the Chief Minister, he was asked to prepare projects on genomics and how he regretted that he had given the situation a pass. He was sure that this time we would prepare a detailed project, regardless of the time and enormity of the effort.

The situation sent us into a dizzy. There was a whirlwind of brainstorming. Our scientists rummaged through all the records to weed out chaff from the wheat. In a short time we compiled the material that ran into 200 pages! We abbreviated most of the material with addition of photographs of stem cells from our lab to about 30 pages. Of course there was one photograph of Mr. Narendra Modi too. We sent it to the PMO. The gist of the project SVISCRTAH runs as under:

Swami Vivekananda institute of stem cell research and therapy and holistic health - SVISCRTAH Proposal

The Proposal is Swami Vivekananda Institute of Stem Cell Research And Therapy and Holistic Health. At the onset it needs to be made clear that there is no contradiction in the proposal. The proposal is the pursuit of science through research and applications so as to provide a unique model for affordable health care. The institution will engage in fundamental research in stem cells and genomics. The facility will apply the proven and established science, but which is not available as yet will get the first platform, following regulatory norms laid down by ICMR. On a larger stage, keeping in Indian traditions, beginning from Rigveda to Bhagawat Geeta such as Bahujana hitaya, bahujana sukhaya, will be the focus (key note address Bhaskar Vyas and Roopa Dave, 2013).

There are phases in drug discovery. Ayurveda and several of the modern medicines rely on herbal preparations. Chemical drug discoveries begin with a molecule with surveillance as to the structure of the molecule and though the peak is already passed, a few drugs still go through organic chemistry route with some alterations in the molecular structure. Biologically derived drugs like antibiotics, also have seen the zenith of the achievements and, with the synthesis of Insulin in the laboratory through the Recombinant RNA route has seen a climax whereby active molecules are synthesized in the laboratory.

$21^{\text {st }}$ Century belongs to the next generation of therapeutic innovations which will be derived from cell based therapy and stem cells. Stem cells are the basis for Regenerative and Rejuvenative process in the body from childhood to old age. The myths and unfounded fears that the science based on stem cells may threaten through the development of teratomas and clones have been practically sorted out. The modern science, as well as ICMR in India has already identified the safe line of cells and stem cells that can be safely researched as well as applied to therapeutics. The Regulatory system, thus treat it in the range of doable category. Several Hematopoietic stem cells are universally in a therapeutic range. It falls upon the Indian geniuses to bring this category of therapeutic stem cell line into Affordable healthcare.

\section{Introduction}

More than a decade ago, that time as the Chief Minister of Gujarat, Shri Narendra bhai Modi foresaw Bharat of today equipped with Biotechnology. Gujarat saw the emergence of Gujarat Biotechnology Mission and 2 Biotechnology parks. The leap came about through a quantum jump of budget of Rupees Ten Thousand crore in the Union Budget in 2014-15. There was a visible clear signal when the Prime Minister of India, probably, the first, visited the Noble laureate Scientist Shinya Yamanaka at Kyoto. It was surely 
to show which direction the Prime Minister wanted India to move ahead in coming years. It was in the direction of science with a focus on Biotechnology which would make new research to become affordable healthcare for vast masses. Kyoto thus became a symbol of aspiration. The Noble laureate almost performed a miracle by translating adult somatic cells to Induced Pluripotent Stem Cells-iPS. While, this will be a mother of enunciation to come, as of today iPS, though it is the highest achievement in stem cell science, remains far from clinical Application. Before iPS is further researched, that the regulatory bodies clear it for an application in research in Human Domain, there are still several cell lines available within the permissible areas of doable research that have been given the new thrust by the Government of India. The Biotechnology sector is capable now of rapid thrust into establishing the facilities for the therapeutic application of established cell lines and simultaneously utilizing the permissible research cell lines so as to develop a new therapeutic range of stem cell derived medication for so far untreatable medical conditions.

There was another thrust by Shri Narendra Bhai Modi as a Prime Minister of India. He sponsored and got it passed at the UN General Assembly that from 2015 the world would celebrate $21^{\text {st }}$ June as the International Yoga Day. It was the Dream of Maharishi Aurobindo that India should emerge as a world teacher. This spiritual aspiration is coming through a pooled circle, now in a scientific paradigm. Last few decades of Advancements in Neuroscience and Psychology have seen the emergence of mind-bodycontinuum. Numerous Cytokines including Endorphins are established as a product of thought processes. The brain has justifiably established itself as the largest Endocrine gland. The linkages of good and bad thought processes to the particular locations in brain are precisely mapped out. What was esoteric, mystic Rajyoga has been studied through the scientific parameters. Several researchers studied Buddhist meditators (and Buddhist meditation is an elaborate version of various strategic programs, initiated by Patanjali) who have discovered the healing properties of strategic meditation programs. What was initially conceptualized as Yoga Nidra by Swami Satyananda Saraswati at Bihar School of yoga, has now been translated under the modern versions of Hypnotheraphy all across the western world. The Bihar School of Yoga was founded in 1964 by Sri Swami Satyananda Saraswati to impart yogic training to householders and sannyasins alike. The Yoga techniques developed there are a synthesis of many approaches to personal development, based on traditional Vedantic, tantric and yogic teachings in conjunction with contemporary physical and mental health sciences. Today, these techniques are taught by Bihar Yoga Bharati and also by Satyananda Yoga Academies in Australia and Colombia. At Simonton Health Centre for Breast Cancer, Dr. O. Carl Simonton, a radiation oncologist popularized the mind-body connection in fighting cancer. Early in his medical career, he noticed that patients given the same dose of radiation for similar cancers had different outcomes. When he looked into why, he concluded that people who had a more positive attitude generally lived longer and had fewer side effects. In a study by Stanford University and the University of California, Berkeley researchers concluded in 1989 that women with advanced breast cancer who received emotional counseling lived about twice as long as those who did not. The study was independent evidence that Dr. Simonton's "whole body" approach to battling the illness made a difference. Dr. Atkins Health Centre for Coronary Artery Diseases is one of the few shining examples in the USA. On the other hand, Dr. Nagendra and Dr. Nagratna at Swami Vivekananda Yoga Anusansthan at Bangalore are a functioning Holistic Health Model. The Swami Vivekananda Yoga Research Foundation was recognized as a Scientific and Industrial Research Organization(SIRO) from the Department of Scientific and Industrial Research, Ministry of Science and Technology, Government of India in the year 1988 as it started following the path breaking work in evaluating the therapeutic use of yoga in the management of bronchial asthma and in other aspects from 1984. The scientific accomplishments thereafter and the disciplined education based on the science and philosophy of yoga resulted in receiving University affiliations leading to a doctoral level program in yoga and allied sciences under the Faculty of Science, Bangalore University. Dean Ornish, M.D., is the founder and president of the non-profit Preventive Medicine Research Institute (PMRI). He brings the future of medicine today-the tools to customize a way of eating, managing stress, and exercising that is based on your own desires, needs, and genetic predispositions. Your genes are not your fate. New research by the Dean, Dr. Ornish and his colleagues shows that changing what you eat and how you live may actually alter, for the better, how your genes are expressed. Matthieu Ricard is the founder of Karuna-Shechen, a charitable non-profit organization rooted in the ideal of compassion in action and also an active member of the Mind and Life Institute, an organization dedicated to broadening the understanding of how the mind works by exploring the intersection between contemplative traditions and contemporary scientific inquiry. He contributes to the research on the effect of meditation on the brain at various universities in the 
USA and Europe. Richard J. Davidson is the William James and Vilas Professor of Psychology and Psychiatry, Director of the Waisman Laboratory for Brain Imaging and Behavior and the Laboratory for Affective Neuroscience. In 2006, he was awarded the first Mani Bhaumik Award by UCLA for advancing the understanding of the brain and conscious mind in healing.

The best concise description about Yoga is in 4 seminal booklets by Swami Vivekananda. The vibrant tradition further got encapsulated by Shri Aurobindo in integral Yoga. B. K. S. Iyangar demonstrated the healing effects of hut yoga that he took to Jay Prakash Narayan and Vinoba Bhave too. Our focus is on the Rajyoga tradition which expounds mind-body-continuum.

The Scientific Parameters were first decided for and published by Maharishi Yogi. Through his research university, MERU (Maharishi European Research University, Switzerland). He published numerous physiological studies on the de-stressing effect of meditation that he postulated to trance and to even a quantum level. Herbert Benson from Massachusetts University, Boston came to Dharamsala to study Meditation under the mentorship of the Dalai Lama. His seminal book, 'the Relaxation Response' (1987) was only next to that of Hans Selye's classic 'Stress of Life' (1955). A cascade of publication in Neuroscience followed the discovery by Candane Pert of Endorphins (Molecules of Emotions 1976). Ernest Rossi, (a friend of Dr. Vyas and co-author) took the mind body connection even to the genetic expression, (The Physiobiology of Gene Expression) and till today has studied fifteen Genes that seem to be either up or down regulated. This may be the Pinnacle of Discovering a continuity of Environment $\rightarrow$ Ideas and Thoughts $\rightarrow$ Brain $\rightarrow$ Molecules in Neurotransmission and Hormone Regulation $\rightarrow$ Cell Regulation $\rightarrow$ Genetics. The Zenith of this pyramid would arrive when the final computations of Large Hadron Colider Experiment (2012) were further analyzed and taken to the next stage of experimentation.

The Concept while it was practiced by Mesmer in Vienna, was simultaneously exported from India by a poor Brahmin to Paris' Abbe Faria. Only in the latter half of $20^{\text {th }}$ century did the altered state of consciousness (all meditative states are altered state of consciousness) emerge as a scientific discipline with implications for therapeutic applications. Dr. Hrishikesh Jana, a professor of physiology established a society in India, Indian Society for Clinical and Experimental Hypnosis (1976) and now they are worldwide. There are wide ranging therapeutic applications (Harvard Medical School 2003).
Thus, though Hypnotheraphy is a product of meditative process, India has very few Hypnotherapists. The fact was brought to the attention of past president of India, Dr. A P J Abdul Kalam, while discussing his book 'The Family and The Nation' which is a discourse with Acharya Mahapragya. He said that India must accelerate towards advancement of Hypnotherapy in scientific model. British Medical Association (1992) and American Medical Association (1958) have approved the therapeutic use of Hypnosis.

We received a reply from ICMR. After careful scrutiny, we understood that though there was not any criticism on the scientific merit, ICMR experts were pointing a finger to go for public cord blood banking. Soon, we received a call from Mr. S to go to the PMO with details.

Rajni and I, accompanied by Amit Goswami, went to the PMO 15 minutes before the appointed time. It was like entering the sanctum sanctorum of the temple that governs whole of India. However, it was like entering any other government office with much tighter security and we were told Mr. Silva Kumar was in a meeting with the PM that could go on for an indefinite time. We could come again the next day or wait indefinitely.

When we met Mr. S after about an hour, it was past 6 P.M. We thought he would be in a hurry to leave for home. Instead, he was well relaxed and joked that there was no scheduled closure time for the PMO.

After brief elaboration, he asked:

"Are you anywhere near discovering a new drug with stem cells?".

"A new drug discovery has not happened to India since Independence. It takes a process that may last 10 years and cost \$130 million. Our two funded projects by the Government of India point a finger that may lead to a new drug discovery".

"You have not mentioned about holistic health in your project".

"The concept about holistic health is well formulated; therefore it does not need elaboration. Baseline is that body and mind are intimately connected. Several conditions may be treated with hypnotherapy. Homeopathy relies heavily on individual mindset of the patient. 
Moreover, we intend to explore Ayurvedic drugs with modern scientific paradigm. This may eventually ensure Ayurvedic drugs a place with pharmacopeia of western countries".

"What can we do for you?".

"Our first requirement is land, about 10 acres. We are ready with a technology to set up a public cord blood bank facility. We have the technical know-how to set up. Both of these will need help from the state government. However, NCCS, Pune has the latest facility for cryo-preservation of cord blood derived stem cells. We will want to be updated at NCCS, Pune for a week".

We established linkage with NCCS scientist Gopal Kundu. We spent almost a whole day with Dr. Lalita Limaye, a gracious gentle lady professor willing to share knowledge. And we also came to know the erudition of Prof. Ulhas Wagh and enjoyed hospitality from ex-director G. C. Mishra. We thought that with this facilitation from the PMO, we would not only gain further insights in technology, but would also save cost. Moreover, present director at NCCS, allowed Dr. Gopal Kundu to collaborate to write a stem cell project at DBT. He asked only one question, “Why don't you do it at M. S. University?". and he was satisfied when we replied that our University had no stem cell research.

We do not know where we went wrong with NCCS this time. Their replies, formally courteous with assurance to concede to our request had a single query. We should be agreeable to pay consultation fees. We readily agreed since our perception of a consultation or observation for a few days would be around 3-4 figures. Thereafter, we were told that after careful calculation, a 5-day observation at NCCS would cost Rs. 5 lakhs!

We understood that this was not a joke. Surely we must have irked or jerked someone the wrong way. The fees of this order were not unusual provided a business house was providing commercial help to another. But here the technology involved a public service: setting up a public cord blood banking facility. Prof. Lalita Limaye had mentored at length on nuances as to why one should not set up a private cord blood banking facility. Out of 45000 samples of cord blood bank stored, there is a possibility that not more than a single child may need the stored cells. It almost amounted to exploiting a mother's love for a child that may really never need cord blood stem cells. Thus we diverted from private cord blood banking to public cord blood banking. Lalita Limaye had cautioned regarding the latter as well. There is only one public cord blood bank functioning all over the world, at New York. The reason is obvious, blood collection and blood disbursement to a patient has to be in full compliance with Helsinki declaration. It was obvious that there had to be a huge network to derive donations and funding for this project.

When we next visited the PMO, Mr. S told us that he was promoted to finance ministry. But, there was another IAS director, Mr. SP who was in charge. We should see him.

Mr. SP was fully aware of the previous meeting, as if we had met him personally. He inquired about NCCS and their response. When we briefed him as to what had happened, he conveyed through body-language, disbelief, annoyance and dejection. He said, "Do you have the copy of the letter?".

"Yes, here it is".

"I would like to pursue the matter, let me have a copy".

"Mr. SP, it is obvious that they do not want us to have this facilitation".

"But we would like to know why? And how they had arrived at such valuations?".

"That will further antagonize them. We have the technology and we know where else to look for verification from other academics. Kindly drop the matter".

SP closed the matter, though it was obvious he had not liked it. It may not have been open defiance but it was certainly insubordination to the highest office in the country. Such 'autonomous' behaviour will not set up any healthy democratic behaviour but will generate fissiparous tendencies.

Both the sides sat in silence for some time. Then we said, "Mr. SP, we leave the decision about how to act to you. We have set our course on moving straight on the stem cell matter and not on engaging in to divertive discord. Kindly oblige by understanding".

We gathered the information that Government of India has an ambitious plan to set up at least one public cord blood banking facility in each state of India. Quoting the reference from the Prime Minister, we followed up with different secretaries in the Dept. of Health; we drew polite non committal answers. We could not get any information about setting up public cord blood banks in every state of India. By this time we came to know that Dr. Srinivisan and 
Dr. Saranya had set up a public cord blood bank at Chennai as Jeevan Public Cord Blood Bank. When Government of Tamil Nadu decided to fund them with $9 \mathrm{Cr}$, we decided to visit them at Chennai.

Dr. Saranya and Dr. Srinivasan had a profile that we found really attractive. Both of them were clinicians. They jettisoned their clinical career when Dr. Srinivasan sold off their pathological lab. They succeeded to get the grant from Tamil Nadu Government as they had formulated the fees that would be very beneficial to Tamil Nadu residents.

\section{Acknowledgement}

We acknowledge help from Vatsal Naik for transcription and pre-publication editing.

\section{Assets from publication with us}

- Prompt Acknowledgement after receiving the article

- Thorough Double blinded peer review

- Rapid Publication

- Issue of Publication Certificate

- High visibility of your Published work

Website: https://www.actascientific.com/

Submit Article: https://www.actascientific.com/submission.php

Email us: editor@actascientific.com

Contact us: +919182824667 